\title{
Social preferences and portfolio choice
}

\author{
Citation for published version (APA):
}

Riedl, A. M., \& Smeets, P. M. A. (2013). Social preferences and portfolio choice. Maastricht University, Graduate School of Business and Economics. GSBE Research Memoranda No. 051 https://doi.org/10.26481/umagsb.2013051

Document status and date:

Published: 01/01/2013

DOI:

10.26481/umagsb.2013051

Document Version:

Publisher's PDF, also known as Version of record

\section{Please check the document version of this publication:}

- A submitted manuscript is the version of the article upon submission and before peer-review. There can be important differences between the submitted version and the official published version of record.

People interested in the research are advised to contact the author for the final version of the publication, or visit the DOI to the publisher's website.

- The final author version and the galley proof are versions of the publication after peer review.

- The final published version features the final layout of the paper including the volume, issue and page numbers.

Link to publication

\footnotetext{
General rights rights.

- You may freely distribute the URL identifying the publication in the public portal. please follow below link for the End User Agreement:

www.umlib.nl/taverne-license

Take down policy

If you believe that this document breaches copyright please contact us at:

repository@maastrichtuniversity.nl

providing details and we will investigate your claim.
}

Copyright and moral rights for the publications made accessible in the public portal are retained by the authors and/or other copyright owners and it is a condition of accessing publications that users recognise and abide by the legal requirements associated with these

- Users may download and print one copy of any publication from the public portal for the purpose of private study or research.

- You may not further distribute the material or use it for any profit-making activity or commercial gain

If the publication is distributed under the terms of Article $25 \mathrm{fa}$ of the Dutch Copyright Act, indicated by the "Taverne" license above, 


\section{Maastricht University}

Arno Riedl, Paul Smeets

Social Preferences and

Portfolio Choice

RM/13/051

\section{GSBE}

Maastricht University School of Business and Economics

Graduate School of Business and Economics

P.O Box 616

NL- 6200 MD Maastricht

The Netherlands 


\title{
Social Preferences and Portfolio Choice
}

\author{
Arno Riedl \\ Paul Smeets
}

August, 2013

\begin{abstract}
This paper explores whether social preferences influence portfolio choices of retail investors. We use administrative investor trading records which we link to decisions of the same investors in experiments with real money at stake. We show that social preferences rather than return expectations or risk perceptions are the main driver of investments in socially responsible (SRI) mutual funds. Social preferences are only associated with investments in SRI funds without tax benefits, but are unrelated to investments in SRI funds with tax incentives. This illustrates that tax incentives change the clientele of mutual funds and that tax incentives crowd out the intrinsic motivations of investors with strong social preferences. Our results also show that prosocial behavior in one domain (experiment) is correlated with prosocial behavior in another domain (investments), which adds to the discussion on the usefulness of experiments in finance.
\end{abstract}

Key words: socially responsible investments (SRI), trust game, social preferences, mutual funds

JEL Classification: G11, D64, H41

Corresponding author: Paul Smeets. Maastricht University School of Business and Economics, Department of Finance (LIFE) and European Centre for Corporate Engagement, PO Box 616, 6200 MD Maastricht, The Netherlands. pm.smeets@maastrichtuniversity.nl. Tel.: +31 (0) 43 3883643. Arno Riedl: CESifo, IZA, Netspar, Department of Economics (AE1), School of Business and Economics, Maastricht University, the Netherlands. a.riedl@maastrichtuniversity.nl This paper was previously entitled "Socially responsible investments: Return Expectations or social preferences?" 


\section{Introduction}

Socially responsible investors create a conundrum as they deviate from the market by excluding certain 'sin' companies from their portfolio or by focusing on companies with good environmental policies, employee relations, and so forth. Paradoxically, it also appears that this deviation from the market is not vanishing but rather increasing. In Europe socially responsible investments are growing in volume (EUROSIF, 2012) and in the United States approximately one in nine dollars of professionally managed assets are involved in social responsible investments (SIF, 2012). A few papers show that socially responsible investments sometimes perform financially better or at least not worse than conventional investments (Bauer, Otten and Koedijk (2005), Derwall et al. 2005, Kempf and Osthoff 2007, Edmans 2011). However, there is also clear evidence that investing socially responsible can be financially costly. For instance, Fabozzi, Ma and Oliphant (2008) and Hong and Kacperczyk (2009) find that divesting from 'sin' industries that involve weapons, tobacco, alcohol or gambling is costly because these companies tend to perform better than 'non-sin' companies. Also Renneboog, Ter Horst and Zhang (2008) find that SRI equity funds underperform relative to conventional equity funds. Given the evidence, the observed deviation from the market portfolio is difficult to explain on the basis of financial performance alone. This suggests that other motives than performance expectations are important in the decision to invest socially responsible.

In contrast to conventional mutual funds, socially responsible mutual funds have a focus on broader societal issues. For example, they invest in companies that respect human rights, invest in good employee relations, focus on environmental protection, etc. (Social Investment Forum, 2012). The societal focus of such funds implies a public good component, suggesting that socially responsible investors are not only interested in their own material well-being but also in the well-being of others. In other words, it seems likely that other-regarding or social preferences are important determinants of socially responsible investments. Bollen (2007) and Hong and Kostovetsky (2012) provide suggestive evidence that this could indeed be the case. The former finds that ex post investors are more likely to hold on to bad performing social responsible investment 
funds than to hold on to bad performing conventional funds. The latter find that Democratic fund managers select stocks that score higher on social responsibility than the stocks selected by Republican fund managers. Importantly, these studies do not directly measure preferences and it is, therefore, unclear whether investors' behavior is indeed influenced by their social or political preferences.

In this paper we directly measure social preferences and provide first evidence of whether such preferences indeed affect portfolio choice by investing socially responsible. This evidence is important, as observed deviations from the market portfolio could influence stock prices in the long run if they were caused by (stable) social preferences and SRI keeps growing at its current pace (Hong and Kacperczyk, 2009). In contrast, differences in performance expectations would probably only generate short run effects on asset prices, because potential mispricing of socially responsible companies should disappear as investors learn over time (Derwall, Koedijk and Ter Horst, 2011). Understanding the role of social preferences is also important for mutual fund managers and pension funds. If investors solely care about risk and return, fund managers should only restrict their investment universe to socially responsible funds if they expect higher risk-adjusted returns on socially responsible companies than on other companies. In contrast, if individuals' investment behavior is also guided by their social preferences fund managers should also focus on the broader societal impact of their investments.

Knowledge about the role of social preferences for portfolio choice could also provide insights into the role of investor preferences in other prominent examples of deviations from the market portfolio, like the home and the local bias (Coval and Moskowitz (1999), Ivković and Weisbenner (2005), Pool, Stoffman and Yonker (2012)), excessive investments in employer stocks (Cohen (2009)) and the investor's car manufacturer (Keloharju, Knüpfer and Linnainmaa (2012)), the evidence on ex post performance of investors exhibiting such biases is quite mixed (Ivković and Weisbenner (2005), Cohen (2009), Pool, Stoffman and Yonker (2012)). Therefore, if social preferences are important in portfolio choice these other deviations from the market portfolio may also have a preference based explanation. 
To assess the role of social preferences in socially responsible investments we use a unique combination of three data sources. First, we gather administrative data from a large mutual fund provider in the Netherlands; second, we conduct incentivized artefactual field experiments; third, we collect additional information through a survey.

The mutual fund provider offers both a large variety of socially responsible and conventional mutual funds, for which investors are personally responsible. That is, they buy and sell their funds directly online without the interference of an intermediary. The administrative data contain the monthly portfolio holdings of retail investors, their returns, and basic demographics. The data also comprise the total amount and proportion of the portfolio invested in socially responsible investment funds with and without tax incentives as well as all investments in conventional mutual funds. For our analysis we link the administrative data to sampled survey responses and behavior in the experiments.

For our purpose, it is important to have an independent measure of social preferences that is as little as possible affected by considerations regarding reputation or strategic fairness (Kreps, Milgrom, Roberts, and Wilson (1982)) and, hence, measures intrinsic social preferences. In order to get such a measure we let investors participate in an anonymous one-shot trust game experiment (Berg, Dickhaut, and McCabe (1995), Fehr and List (2004), Karlan (2005), Baran, Sapienza and Zingales (2010)). The trust game is a two player sequential game where the first-mover can transfer money to a second-mover. The transferred amount is tripled by the experimenter. The second-mover can send back nothing, parts, or all of the received money to the first-mover. It is the behavior of investors in the role of second-movers which endows us with the measure of social preferences. In a case where the second-mover is fully selfish he should not send back any money. The more an investor returns, the stronger are his or her social preferences. We avoid repeated game effects by the one-shot nature of the experiment and minimize potential reputation effects through the anonymity of investors. We are, therefore, confident that the amount sent back by the second-mover is indeed a good measure of intrinsic social preferences. Moreover, second-mover behavior in trust games has already been shown to have predictive power for prosocial field behavior (Karlan 
(2005), Baran, Sapienza and Zingales (2010)). Next to the trust game, investors also participate in a financially incentivized risk preferences elicitation task (Holt and Laury (2002) and Dohmen et al. (2011)). This gives us an independent measure of risk preferences and allows us to control for risk preferences when examining the factors determining investors' portfolio choice.

The third element in our empirical research strategy consists of the survey data. Such data are useful for eliciting factors that are otherwise difficult to gather (see, e.g., Guiso, Sapienza, and Zingales (forthcoming)). In identifying whether social preferences are an important determinant for investing socially responsible we need to control for individual differences in return expectations and risk perceptions regarding conventional and socially responsible investments. As these variables are not available in the form of administrative data on the individual level, we use survey questions to gather them. In addition, we also use survey questions to get data on other control variables that are potentially important for investment behavior, like investment knowledge, income level, age, gender, etc.

Our main results can be summarized as follows. We find clear evidence that social preferences matter in portfolio choice. In particular, investors with stronger intrinsic social preferences are more likely to hold SRI funds without tax incentives. Interestingly, this is not the case for SRI funds with tax incentives. Moreover, in contrast to social preferences, expectations about the returns of and risk perceptions on SRI funds are unrelated to investments in SRI funds. Hence, our evidence supports a preference-based explanation for portfolio distortions rather than a belief-based explanation. The finding that intrinsic social preferences are unrelated to investments in SRI funds with tax incentives is also important in light of the literature on intrinsic and extrinsic motivation (Gneezy and Rustichini (2000 a,b), Benabou and Tirole (2006), Ariely, Bracha and Meier (2009)). It shows that SRI funds with extrinsic incentives attract different investor types than SRI funds without such incentives. We also discuss the possibility that investors use SRI as a device to signal pro-social motivations. In that respect, our evidence suggests 
that investors with stronger intrinsic social preferences are less likely to use socially responsible investments as a signal to improve their pro-social reputation.

\section{Hypothesis development and literature review}

In this section, we derive our main hypothesis that social preferences have an important influence on portfolio choice in the form of socially responsible investments. We first discuss potential financial reasons to invest in SRI funds, followed by evidence of the effect of social preferences on other economic choices and third talk about the role of social preferences in financial decisions.

\subsection{Financial reasons to invest in SRI funds}

According to modern portfolio theory, investors create portfolios based on an optimal risk-return trade-off. For socially responsible investments this implies that investors would never hold SRI funds if they thereby worsened the risk-return profile of their portfolio. Hence, given the increasing interest in socially responsible investments (EUROSIF (2012), SIF (2012)) one should expect that SRI funds perform at least as well as the market. Some papers suggest that SRI funds could potentially outperform conventional funds or that the performance is the same, but others find that SRI funds underperform compared to other funds (Bauer, Otten and Koedijk (2005), Kempf and Osthoff (2007), Fabozzi, Ma and Oliphant (2008), Renneboog, Ter Horst and Zhang (2008), Hong and Kacperczyk (2009), Edmans (2011)). Therefore, it is unlikely that the steady growth in socially responsible investments can be explained by financial reasons alone. However, if investors differ in their subjective (out-of-equilibrium) expectations it may still be that some investors (incorrectly) expect SRI funds to financially outperform other funds. We will, therefore, control for these beliefs in our analysis.

An alternative financial motivation could be differential tax treatment. In the Netherlands, where our data set is gathered, certain types of SRI funds indeed offer tax benefits. In order to explore the role of tax benefits we will analyze the determinants of investing in SRI funds with and without such preferential tax treatment. 


\subsection{Social preferences: theory and empirical evidence}

There is mounting evidence from the laboratory and the field that people often do not only care about their own material well-being but as well care about the well-being of others (see, e.g., Ledyard (1995), Fehr and Gächter (2000), Karlan (2005), Egas and Riedl (2008), Falk and Heckman (2009)). ${ }^{1}$ Such social (aka other-regarding) preferences constitute a profound deviation from the standard neoclassical homo economicus assumption still prevalent in the finance literature. We are interested in whether social preferences are also important in portfolio choice an area hitherto neglected in finance as well as by research on social preferences.

\subsection{Social preferences and investments}

Recent evidence in finance suggests that investors' preferences over non-material values, like political preferences, can influence portfolio choice (e.g. Bollen (2007), Kaustia and Torstila (2011), Hong and Kostovetsky (2012), Kumar and Page (forthcoming)). The evidence that is provided by these studies, however, is indirect as they do not measure preferences over immaterial values. It is, therefore, unclear whether investors deviate from holding the market portfolio because of their preferences or because of some other (unobserved) variable. For instance, Hong and Kostovetsky (2012) find that Democratic fund managers are more likely to invest in stocks with good social responsibility than are Republican fund managers. It could be that Democratic investors (incorrectly) expect that socially responsible stocks outperform the market.

We hypothesize that it is indeed social preferences that (co-)determine portfolio choice. Specifically, we hypothesize that investors with stronger social preferences are more likely to invest in socially responsible mutual funds (Hypothesis I). Moreover, as

1 For theoretical approaches modeling such behavior see, among others, Rabin (1993), Andreoni (1990), Fehr and Schmidt (1999), Bolton and Ockenfels (2000). See Sobel (2005) for a critical discussion. 
discussed in section 2.1 investors with purely financial motives could hold SRI funds for reasons of preferential tax treatment. We investigate this issue and hypothesize that social preferences are positively related to investments in SRI funds without tax benefits but are unrelated (or at least weaker related) to investments in SRI funds with tax benefits (Hypothesis II). The reason is that the latter can be held for financial reasons by investors not motivated by social preferences. Moreover, it has been shown that extrinsic incentives sometimes can crowd out intrinsic pro-social motivations (Gneezy and Rustichini (2000 a,b), Benabou and Tirole (2006)). Therefore, it may even be that investors with strong social preferences prefer not to invest in funds with tax benefits.

\section{The data}

In this section, we first describe the administrative investor data, followed by a description of the survey and details on the experiments. We then describe our main variables.

\subsection{Administrative investor data}

We utilize administrative individual investor data from one of the largest mutual fund providers in the Netherlands, covering the period January 1992 - August 2012. The mutual fund provider offers a wide range of investment funds, including equity funds, bond funds and mixed funds. ${ }^{2}$ Within these categories the funds can be global, sectorspecific, socially responsible funds, and so on. Especially important for our study, the administrative data show for each investor whether or not s/he holds a socially

2 Figure A1 in the appendix shows a screenshot of the product selector of the mutual fund provider. The product selector shows for each fund to which category it belongs and whether the provider classifies the fund as sustainable, emerging markets, global, etc. At the same screen, investors can read about the details of the fund including the details regarding stock selections based on social responsibility criteria. In addition, the product selector gives information such as past performance, Morningstar ratings and fees. 
responsible mutual fund and the shares invested in SRI funds and all other funds, on a monthly basis.

Moreover, for investors holding SRI funds we can distinguish between money invested in SRI funds that offer tax benefits and SRI funds without tax benefits. The former are SRI bond funds for which the Dutch government gave tax incentives that could reach a maximum of $2.2 \%$ of the amount invested in the month relevant for the study. ${ }^{3}$ The reason that these funds offer tax benefits is of political nature as the money is invested in specific companies or projects that the Dutch government wants to subsidize (e.g., producers of windmills and organic farmers). These SRI funds with tax benefits are equity funds comparable to SRI equity funds offered in the United States (SIF, 2012) and the rest of Europe (EUROSIF, 2012). Fund managers of SRI funds with tax benefits are thus restricted in their investment choices. In contrast, managers of SRI funds without tax benefits are free in the selection of companies in which they invest. SRI funds with tax benefits are defined by Dutch tax law, which is also the definition we use. For SRI funds without tax benefits we use the classification of the mutual fund provider of socially responsible and sustainable funds. ${ }^{4}$

\subsection{The survey}

Survey questions have some known limitations. For instance, participants might differ from non-participants and the answers of respondents may depend upon the framing of the questions. We discuss a potential response bias in our results below and conclude that if a response bias is present, they likely weaken the effect sizes that we identify and we,

3 If not stated otherwise all used administrative investor data refer to the month when the survey and experiment were conducted (June 2011).

4 The survey indicates that $83 \%$ of all investors (also those who do not hold SRI funds) respond positive or neutral to the statement that socially responsible investments have a positive influence on society. Only $26 \%$ of the investors indicate in another statement that they believe that SRI funds are a marketing trick to sell more funds. We are therefore confident that funds defined as SRI funds are also perceived as such by most investors. 
hence, are on the conservative side. Regarding framing effects, it is important to note that all investors received similarly framed questions. Because we are primarily interested in the different beliefs and attitudes of socially responsible and conventional investors, the effects of framing should be equal for both groups. Surveys also have major benefits. In our case, it allows us to measure return expectations and risk perceptions that would otherwise remain unobserved. Moreover, we can also gather information on additional important control variables, like their self-rated investment knowledge, income level, gender, age etc.

The administrative data provide information on 3,382 socially responsible investors, which were all invited to participate in the survey. Next to the socially responsible investors, we randomly selected about 35,000 investors of the approximately 145,000 remaining accounts in the database. ${ }^{5}$ All selected investors received an email that contained a link to the online survey in spring 2011. The response rate was $8 \%$ for conventional investors and $12 \%$ for socially responsible investors (see Table A1 in the appendix for a comparison the two samples regarding several important variables observed in the administrative data). We on purpose invited disproportionately more SR investors to increase the power of the analyses that compare SR investors to conventional investors. Relative to the invited sample, there are slightly more men, older investors and investors with a larger portfolio, among the respondents. We control for these and other demographics in our analyses.

In the online survey investors answered questions and took part in experiments with monetary incentives (for details see below). At the beginning of the online survey respondents received some general information. In addition, they were also informed that they would take part in several experiments, but were not informed about the content of the experiments until they actually took place. In this introduction also the general procedure regarding possible money earnings in the experiments was explained. In the first part of the survey, we asked about general investment issues like the assets held, the

5 We excluded investors that were no longer holding the account at the time we conducted the survey. We also did not invite investors that never placed a single trade and that were younger than 18 years. 
number of investment accounts and investment goals. In this first part, investors also participated in a risk preferences elicitation experiment. Thereafter, more questions on investment behavior followed. Somewhere in the middle of the survey investors participated in an experiment eliciting their intrinsic social preferences. We asked all survey questions regarding socially responsible investing and social behavior after the experiments.

\subsection{The experiments}

Investors participated in a risk preferences elicitation experiment and in an interactive experiment with other investors where we elicited their social preferences. Investors were informed that at the end of the survey it would be determined randomly (with a chance of one out of ten) whether they will receive the earnings from the experiment or not. ${ }^{6}$ Those who were selected for payment got one of the experiments paid out at random. Investors received their earnings via bank transfer at the first working day after they completed the survey and payments were guaranteed by the authors' university. We used a unique identification number to link the choices in the experiments and responses to the survey to our administrative data. We hired an external company specialized in conducting online research to handle the payments. This company does not have access to the trading records or other information of the investors. This procedure ensures the anonymity of investors. Survey participants were informed about these procedural details at the beginning of the survey.

\section{Risk preferences elicitation experiment}

We elicit risk preferences with incentivized multiple price list lotteries, similar to Holt and Laury (2002) and Dohmen et al. (2011). Investors faced 20 different decision situations and for each situation they decided between receiving a specific sure amount

6 For a recent validation of this procedure, see Dohmen et al. (2011). 
and a lottery with a 50\% chance of winning 300 euro and a 50\% chance of winning nothing. The sure amount was minimally 0 euro and maximally 190 euro and increased in steps of 10 euro from one to the next decision situation. The presented choice options can be found in Table A2 in the appendix. It was determined randomly which of the 20 decisions is relevant for earnings. ${ }^{7}$

The choices made by participants in each of the 20 decision situations inform us about their risk preferences. We use the point at which individuals switch between the lottery and the certain outcome as a measure of risk aversion. As the sure amount is ordered from low to high, a higher switching point indicates a more risk averse participant.

\section{Social preferences elicitation}

To measure intrinsic social preferences, we use a variant of the trust game experiment introduced by Berg, Dickhaut and McCabe (1995). The trust game is a two-player sequential game. In our version, both the first mover and the second mover are endowed with 50 euro. The first mover decides on the amount he or she wants to send to the second mover, which can be any multiple of 5 euro, including zero and 50 . The amount sent is tripled by the experimenter and the second mover decides how much of the received money to return to the first mover. Hence, the earnings of the first mover are 50 euro minus the amount sent plus the amount returned by the second mover. The earnings of the second mover are 50 euro plus triple the amount sent by the first mover minus the money sent back.

Investors received instructions of the experiment online and had to answer a couple of comprehension questions about the rules of the game and how the payment is calculated before the experiment started. These questions were correctly answered by

\footnotetext{
7 The experimental instructions are available upon request.
} 
$89.5 \%$ of the investors. ${ }^{8}$ Importantly, to exclude repeated game and reputation effects the trust game was played only once and investors were informed that they and the other participants in the experiment would remain anonymous during and after the experiment.

In order to obtain a comprehensive measure of social preferences as well as for practical implementation reasons, we use the so-called strategy method (Selten, 1967), for second movers. Specifically, a second mover decides how much to send back, for each of the 11 possible amounts sent by the first mover - ranging from 0 euro to 50 euro. For other successful implementations of the strategy method see, e.g., Falk and Zehnder (2007), Baran, Sapienza and Zingales (2010) and Falk, Meier and Zehnder (2012).

Each investor was either a first or a second mover. We randomly match each second mover to a first mover and only the amount actually sent by the first mover determines the earnings. Moreover, second movers in the trust game are randomly assigned to one of two conditions. Under one condition, they are matched to a first mover who is a randomly chosen investor participating in the survey and the experiment. In the other condition, a second mover is randomly matched to a first mover who is a socially responsible investor participating in the survey and the experiment. We inform subjects in the introduction to the experiment in which condition they are, without telling them that there are two different conditions.

The fact that the trust game is played only once rules out any repeated game effects. Moreover, second movers know that their behavior will never be revealed to anybody and is also only anonymously known to the experimenters, which minimizes reputation effects. Therefore, we can use second-mover behavior as an independent measure of their intrinsic social preferences. In Section 4.1 we specify two measures in more detail. ${ }^{9}$

8 We run our main analysis with all investors and confirm in unreported regressions that the results stay the same when excluding investors who answered incorrectly to at least one question after three trials.

9 We also have data on the behavior of first movers in the trust game, but do not report on them here for brevity and because it is rather a measure of trust and not of prosocial behavior per se. 


\subsection{Variable descriptions}

All variables used in this paper are defined in Table $1 .{ }^{10}$ We first discuss the main variables from the administrative transaction data, second the survey questions, and third the experiments.

\section{<INSERT TABLE 1 ABOUT HERE $>$}

\section{Administrative data}

Panel A of Table 2 shows that $14 \%$ of the investors in our sample hold SRI mutual funds. This percentage is not too far off the $18 \%$ for Dutch investors in general (Millward Brown, 2011). Panel A further shows that socially responsible investors on average hold $14.9 \%$ of their portfolio in SRI funds while the remaining $85.1 \%$ are invested in conventional funds. Of the socially responsible investors, $19.5 \%$ only have SRI funds with tax incentives, $68.4 \%$ only have SRI funds without tax incentives and $12.1 \%$ hold both types of SRI funds.

As a proxy for wealth, we use the (logarithm) of the total portfolio value in the month in which the investors participated in the survey and experiment. The average portfolio value of socially responsible investors is 106,678 euro (S.D. $=190,033$ ), compared to 73,250 euro (S.D. $=127,344)$ for conventional investors. This difference is statistically significant (Mann-Whitney, $\mathrm{p}=0.000$ ) (Table 2, Panel B).

<INSERT TABLE 2 ABOUT HERE $>$

10 The original questions in Dutch are available upon request. 


\section{Survey questions - Return expectations and risk perceptions}

To measure the returns that investors expect on SRI equity funds compared to conventional equity funds, we used the statement: "I expect that the returns of socially responsible equity funds compared to conventional equity funds are: Much lower, A bit lower, The same, A bit higher, Much higher, I do not know." Only 3\% of the socially responsible and $10.3 \%$ of the conventional investors choose "I do not know." To measure risk perceptions of SRI equity funds compared to conventional equity funds, we asked investors to rate their agreement to the following statement: "Socially responsible equity funds are more risky than conventional equity funds." They rated their agreement on a 1-7 scale from 1 'Disagree completely" to 7 "Agree completely."

\section{<INSERT FIGURE 1 SOMEWHERE HERE> <INSERT FIGURE 2 SOMEWHERE HERE>}

In order to explore the determinants of whether an investor holds or does not hold SRI, we first examine whether conventional and socially responsible investors differ in their expectations regarding the returns of SRI. Figure 1 depicts the distribution of return expectations of investors for SRI equity in comparison to conventional equity funds (as defined in Table 1). The figure suggests that SR investors are slightly less pessimistic about returns of SRI than conventional investors. For instance, $51.9 \%$ of the socially responsible investors and $59.7 \%$ of the conventional investors expect to earn much or a bit lower returns on SRI funds than on conventional funds. The difference in distributions is statistically significant (Kolmogorov-Smirnov $(\mathrm{KS})$ test, $\mathrm{p}=0.011$, two-sided). ${ }^{11}$ Figure 2 shows that the distribution of perceived riskiness of SRI equity funds relative to conventional equity funds (as defined in Table 1) is very similar for SR investors and conventional investors. For both investor types the median (mean) score is 4 (3.6), which

11 We also run Mann-Whitney (MW) and t-tests to compare distributions. For that we encode the answers to the question on a Likert-scale from $1=$ much lower to $5=$ much higher. The results are similar (twosided $\mathrm{p}=0.0002$ for both tests). 
is also the median (mean) score of the whole sample. Statistical tests corroborate that there is no difference in the distribution of perceived riskiness of SRI between investor types ( $\mathrm{p}>0.329$, two-sided KS, MW, t-tests). Hence, both SR and conventional investors think that both fund categories carry similar risk.

Notwithstanding the small quantitative difference, the discussed data reflect that both investor types are rather pessimistic about return expectations of SRI funds and perceive the riskiness of such funds similarly. This suggests that other motives than return expectations or risk perceptions must (also) play a role in the decision to invest into SR equity funds. Yet, another possibility could be that investors hold SRI funds for risk diversification reasons. Even if investors perceive the risk of SRI equity funds in isolation as about the same as the risk of conventional equity funds, they may want to reduce the overall portfolio risk by including SRI funds into their portfolio. Our survey data show that this motive is virtually absent. Only $5.1 \%$ of all SR investors indicate to hold SRI funds because of diversification benefits.

\section{Survey questions - Other variables}

With the survey we could also gather additional information of investors not provided in the administrative data. Investors rated their agreement to several statements on a 1-7 scale from 1 "Disagree completely" to 7 "Agree completely." We measured their selfrated investment knowledge by the statement: "My investment knowledge is good." A similar question is used by Dorn and Huberman (2005), Graham, Harvey and Huang (2009), Van Rooij, Lusardi and Alessie (2011). Socially responsible investors rate their knowledge as 4.19 on average (S.D. $=1.31)$ compared to 3.83 for conventional investors (S.D. $=1.47$ ). This difference is highly significant (Mann-Whitney, $\mathrm{p}=0.000$ ) indicating that socially responsible investors rate their investment knowledge higher than conventional investors.

To get a proxy for the extent to which investors can potentially get reputation benefits from socially responsible investments, we use the statement: "I often talk about 
investments with others." Socially responsible investors on average rate their agreement as 3.11 (S.D. = 1.51), compared to 2.91 (S.D. $=1.52$ ) for conventional investors. The differences is statistically significant (Mann-Whitney, $\mathrm{p}=0.001$ ).

\section{Experiments}

Panel B of Table 2 also shows the risk preferences elicited by the experiment. Recall that the risk neutral switching point is 150 euro (50\% chance to win 300 euro and $50 \%$ chance to win nothing). The average switching point for socially responsible investors is 113.29 euro (S.D. $=41.57$ ), compared to 112.23 euro (S.D. $=42.83$ ) for conventional investors. This implies that both groups of investors are on average risk averse and the difference in risk preferences between SR and conventional investors is insignificant (Mann-Whitney, $\mathrm{p}=0.723)$.

\section{Results}

In this section we test our main hypotheses. We distinguish between socially responsible and conventional investors using the administrative data. ${ }^{12}$

\subsection{Social preferences and investments in SRI funds}

We first test Hypothesis I that social preferences are an important determinant for investors to hold SRI funds. The first explanatory variable is our measure of the strength of intrinsic social preferences of investors. As explained in the experimental design section, we can use the behavior of second-movers in the trust game. Recall that we used the strategy method and that second-mover investors had to decide how much money to return for each possible amount of money received from first-mover investors, which

12 If not stated otherwise, the administrative data refer to the month in which investors participated in the experiments and survey. In principle, it is possible that investors only hold SRI funds for a very short period. Therefore, in unreported analyses we conduct all tests and regressions also for investments into SRI funds exactly one month after the survey and experiment in 2011. The results are qualitatively similar. 
lead to 10 decisions. There are several possibilities how to aggregate these decisions in order to arrive at a measure of intrinsic social preferences. We look at two natural measures. For the first measure, we calculate the average return ratio across all 10 decisions. In other words, for each possible first mover transfer (i.e., 5 euro, 10 euro, ..., 50 euro) we calculate the ratio of the back-transfer and take the average. As a second measure we use the absolute amount a second-mover investor returns for the largest possible first-mover transfer of 50 euro. ${ }^{13}$ For convenience, in the regressions the variable is called "intrinsic social preferences", irrespective of the used measure.

Figure 3 shows that for each possible transfer by the first mover, second-movers return more if they are a socially responsible investor than if they are a conventional investor ${ }^{14}$. Panel B of Table 2 shows that the average return ratio of socially responsible investors is 1.53 and that of conventional investors is 1.42 (Mann-Whitney, $\mathrm{p}=0.087$ ). Baran, Sapienza and Zingales (2010) argue that the amount returned by second-movers for the maximum transfer (50 euro) is the best measure for social preferences because the stakes are the highest for this decision. For this maximum first mover transfer, socially responsible investors on average send back 77.46 euro $($ S.D. $=34.49)$ and conventional investors 71.61 euro (S.D. = 34.89). The difference is statistically significant (MannWhitney, $\mathrm{p}=0.061$ ).

\section{$<$ INSERT FIGURE 3 ABOUT HERE $>$}

Next, we test for the previous findings more formally, while controlling for return expectations of SRI, perceived risk of SRI, and other control variables to be specified below. We will present two kinds of regression analyses. In the first we examine the determinants of the likelihood to hold at least one SRI mutual fund and in the second we

13 For the latter measure, Baran, Sapienza and Zingales (2010) show that it correlates strongly with donations, another domain of prosocial behavior.

14 The amount that investors return in the trust game is not significantly different for the two matching conditions described in section 3.3: an average return ratio of 1.44 compared to 1.40 (F-test, $\mathrm{p}=0.216$ ). Observations in both conditions are therefore pooled in the remaining analysis. 
explore what determines the fraction of the total portfolio invested in SRI mutual funds by investors. We next explain the set of explanatory variables.

To control for return expectations and perceived risks of SRI we use the answers to the survey questions regarding risk and return expectations on SRI funds (Figures 1 and 2). For the regression analyses we create a dummy variable (Low expected returns on SRI) for expected returns on SRI that takes on value 1 if an investor believes that the expected return of a SRI fund is lower than the expected return of a conventional fund and zero otherwise. Similarly, for risk perception on SRI we create a dummy variable (Low perceived risk on SRI) that takes on value 1 if an investor believes that the return risk of a SRI fund is lower than the one of a conventional fund and zero otherwise ${ }^{15}$.

To control for investment knowledge we employ three measures used and validated in related literature. We use, first, the $\log$ of the total portfolio value of an investor (Calvet, Campbell and Sodini (2009), Keloharju, Knüpfer and Linnainmaa (2012)), second, investors answers to a financial knowledge question where they had to rate themselves on a 7-point Likert-scale from very poor to very good (Van Rooij, Lusardi and Alessie (2011), Dorn and Huberman (2005), Graham, Harvey and Huang (2009)), and third, a dummy variable indicating whether an investor has a university degree.

We also control for investors' risk preferences as independently measured by the switch amount in our experimental risk preference elicitation task. Further control variables we include are gender (Female, which takes on value 1 if the investor is a woman, zero otherwise) and age (Age) of investors. We also use survey responses to control for Low Income, High Income and Untold Income, with Medium Income being the omitted reference category (for a precise definition of these variables, see Table 1).

15 We use dummies for return expectations and risk perceptions of SRI funds instead of the scores themselves because it reduces the noise in the data, as there are relatively fewer observations in the extreme categories (see Figures 1 and 2). Moreover, generally the sores cannot be interpreted as linear variables. Nevertheless, to check for robustness, we have repeated the analyses with scores instead of dummies and find that all results remain qualitatively unchanged (see Table A3 in the appendix). 
In order to examine the likelihood that an investor holds at least one SRI fund in the portfolio we run probit regressions in which the dependent variable is a dummy that takes on the value of 1 if an investor holds an SRI fund and 0 otherwise ${ }^{16}$. Table 3 shows the results. It presents marginal effects for the ease of exposition.

\section{<INSERT TABLE 3 ABOUT HERE >}

We focus first on the specification where we use the average return ratio as a measure of the strength of Intrinsic Social Preferences (column (1) in Table 3). The table shows that stronger intrinsic social preferences have a significantly positive effect on the likelihood to invest socially responsible $(\mathrm{p}=0.049)$. Specifically, an investor with a 1 point higher average return ratio is 4.05 percentage points more likely to have SRI funds in the portfolio, which is a relatively large effect compared to the $14 \%$ of our sample that holds SRI funds. The result is similar when using our second measure of Intrinsic Social Preferences (column (2) Table 3). The regression table shows that an individual who sends back 10 euro more in the trust game is 0.80 percentage points more likely to hold SRI funds $(\mathrm{p}=0.044)$. To illustrate the economic effect, consider an investor with a strength of intrinsic social preferences that makes him/her sending back an amount that equalizes earnings with the first-mover investor in the trust game experiment. Our regression result indicate that such a socially motivated investor is 8.3 percentage points more likely to invest socially responsible than a completely selfish investor (who returns nothing as second-mover in the trust game experiment).

As already suggested by the results reported at the beginning of this section, expectations about the returns of SRI funds (in comparison to conventional funds) are statistically insignificantly related to the likelihood to invest socially responsible $(\mathrm{p}=$ 0.277). Similarly, differences in risk perceptions about SRI funds do not significantly

16 The total number of observations in the regressions is lower than the overall response rate to the survey. The reason is that investors were randomly assigned to different experiments and to a different role in the trust game. For instance, first movers in the trust game do not appear in our analyses. 
contribute to the likelihood of holding SRI funds $(\mathrm{p}=0.336)$. This holds irrespective of the measure used for Intrinsic Social Preferences.

Table 3 further documents that investors with a larger portfolio (Log Total Portfolio Value) and with a higher rating of their Investment Knowledge are significantly more likely to invest socially responsible. The economic effects of these variables are similar in both reported regressions. Regarding the portfolio size, an investor with a $100 \%$ larger portfolio is about 4.3 percentage points more likely to invest socially responsible $(\mathrm{p}=0.000)$. This relatively strong effect is no surprise as investors with larger portfolios likely spread their larger wealth over various funds, including SRI funds. For investment knowledge the table shows that an investor who rates his/her investment knowledge one point higher on a 1-7 scale is between $1.86 \%$ and $1.89 \%$ more likely to invest socially responsible $(\mathrm{p}<0.090)$. Importantly, none of the other characteristics significantly affects the probability to invest socially responsible.

To explore whether the reported results on the likelihood to hold SRI funds are robust, we now examine the determinants of the percentage of SRI funds an investor holds in the portfolio. For that purpose, we conduct a Tobit regression that accounts for the censoring in the SRI share at $0 \%$ and $100 \%$. Table 4 shows the results and reports the marginal effects of the explanatory variables.

\section{<INSERT TABLE 4 ABOUT HERE >}

The results in Table 4 show that investors with stronger intrinsic social preferences invest a larger share of their portfolio in SRI funds, which is consistent with the regression results regarding the likelihood of holding SRI funds reported above. For the first measure of social preferences, a one point higher return ratio is associated with an increased investment into SRI funds of $5.47 \%$ of the portfolio. For our second measure the result is similar. An investor who sends back 10 euro more in the trust game holds an additional $1.05 \%$ of his/her portfolio in socially responsible funds $(\mathrm{p}=0.054)$. 
The other explanatory variables also show a similar pattern as in the probit regressions. Specifically, return expectations and risk perceptions are not significantly related to the percentage of the portfolio that is invested socially responsible $(\mathrm{p}>0.298$ for expected returns and $\mathrm{p}>0.455$ for risk perceptions). In both Tobit regressions also the portfolio size is significantly positively related to the percentage of SRI in an investor's portfolio. Specifically, a $100 \%$ larger total portfolio size leads to about an extra $3.3 \%$ in SRI funds $(\mathrm{p}<0.013)$. Qualitatively, the only difference to the probit regressions is that now having a university degree predicts a higher fraction of SRI in the portfolio while self-reported investment knowledge is insignificant. In both regressions having a university degree increases the SRI share by about $7.2 \%(\mathrm{p}<0.059)$.

To summarize, we find clear evidence that social preferences are an important determinant for the likelihood to invest socially responsible as well as for the fraction of SRI in an investor's portfolio. Next to social preferences the size of an investor's portfolio is related to investing socially responsible. Intriguingly, neither return expectations nor risk perceptions regarding SRI relative to conventional funds correlate with SRI. Taken together, these results point rather towards a preference-based explanation for investments in SRI funds than a belief-based explanation.

\subsection{Social preferences and the role of tax benefits in investing socially responsible}

As explained in Section 2, investors could choose for SRI mutual funds with or without tax benefits. In this section we test Hypothesis II that investors with strong social preferences are more likely to buy SRI funds without tax benefits but not more likely to buy SRI funds with tax benefits. We run a multinomial logit regression in which the dependent variable takes on four different values. The base group that is not reported consists of conventional investors. The other groups are investors who (1) only hold an SRI fund with tax benefits, (2) only hold an SRI fund without tax benefits, (3) hold both types of SRI funds. Since the results for our two measures of intrinsic social preferences 
were almost identical in the previous analyses, for brevity we only report the results for the average return ratio here. ${ }^{17}$

\section{<INSERT TABLE 5 ABOUT HERE>}

Table 5 reports relative-risk ratios for the same set of explanatory variables as in the previous section. Consistent with our hypothesis, we find that an investor with stronger intrinsic social preferences is more likely to hold an SRI fund without tax benefits. Specifically, column (2) of Table 5 shows that an investor with a one point higher return ratio in the trust game experiment is $47.9 \%$ more likely to only hold an SRI fund without tax benefits than being a conventional investor, i.e., holding no SRI fund ( $p$ $=0.027$ ). Investors with stronger social preferences are insignificantly more likely to hold both SRI funds with and without tax incentives $(\mathrm{p}=0.227)$ and insignificantly less likely to hold only SRI funds with tax benefits $(\mathrm{p}=0.528)$.

In line with our results reported in the previous section, return expectations and risk perceptions are insignificant. Investors with a larger total portfolio size are in general more likely to hold any type of SRI fund or both types. The coefficients are significant in all three columns. For example, an investor with a $100 \%$ larger portfolio is, compared to the base group, $66.9 \%$ more likely to only hold an SRI fund with tax benefits, $29.5 \%$ more likely to only hold an SRI fund without tax benefits and $128.1 \%$ more likely to hold both types of funds. This result is consistent with our interpretation that wealthier investors tend to diversify more and also include SRI in the diversification. In addition, investors who rate their investment knowledge one point higher on a 1-7 scale are $83.9 \%$ more likely to only hold an SRI fund with tax benefits than to only hold conventional funds (base group) ( $\mathrm{p}=0.008$ ). There is no investment knowledge effect for the other investor groups. We also find that having a university degree marginally increases the likelihood to hold SRI funds with and without tax benefits $(\mathrm{p}=0.064)$. Whereas being

17 The results remain robust when using the other measure of intrinsic social preferences (see Table A4 in the appendix). 
female and being older each has a marginally negative effect on holding only SRI funds with tax benefits ( $p=0.074$ and $p=0.056$, respectively).

We have argued that next to social preferences higher return expectations due to tax benefits could be a reason for holding SRI. This explanation would be consistent with the above analysis. Alternatively, however, some investors could hold SRI funds for reputational reasons and thus tend to hold tax beneficial SRI funds. These funds have lower financial costs (in terms of expected return) than non-tax beneficial SRI funds and could therefore be attractive for such investors. We further discuss this issue in Section 4.3 below.

An important difference between SRI funds with and without tax benefits is that the former are bond funds whereas the latter are equity funds (cf. Section 2). Therefore, risk averse investors might prefer SRI funds with tax benefits over SRI funds without tax benefits. We addressed this issue in three ways. First, we control for risk preferences in the regressions reported in this section. Second, as $99 \%$ of the socially responsible investors only invest part of their portfolio in SRI funds, their overall portfolio combines conventional equity and bond funds with SRI equity and SRI bond funds to achieve the desired level of portfolio risk. Third, we control for monthly portfolio returns and the average monthly standard deviation of portfolio returns in a robustness multinomial logit regression reported in Table 6 . Adding these controls does not change the result regarding the effect of social preferences. Investors with stronger intrinsic social preferences are substantially more likely to invest in SRI funds without tax incentives while there is no effect on the likelihood to have SRI funds with tax benefits. In fact, the coefficients on intrinsic social preferences are almost identical with the result reported in Table 5.

\section{<INSERT TABLE 6 ABOUT HERE>}

To shed more light on the financial motivations of socially responsible investors, we asked them for their main reason to invest socially responsible. Investors could choose from different categories and we define financial reasons as either 'tax benefits', 
'higher expected returns', 'a better risk-return trade-off' or 'risk diversification'. The data show that $27.2 \%$ of the investors give a financial reason to invest socially responsible. Figure 4 shows that investors who only hold SRI funds with tax benefits are most likely to give a financial reason for investing in SRI funds (43.9\%), whereas only 35.7\% of investors who hold both types of SRI funds and $21.8 \%$ of the investors who only hold SRI funds without tax benefits report a financial reason. This difference is statistically significant (Kruskal-Wallis test, $\mathrm{p}=0.0001$ ). This evidence corroborates the finding that investors who are more prosocial in the experiment are only more likely to invest in SRI funds without tax benefits, because SRI funds with tax benefits attract many investors with financial motivations.

\section{<INSERT FIGURE 4 SOMEWHERE HERE>}

\subsection{Intrinsic social preferences and reputation}

So far, we have shown that investors with stronger intrinsic social preferences are more likely to invest in socially responsible funds, especially in SRI funds without tax benefits. However, SRI funds are also held by investors without strong social preferences and especially the holding of SRI funds with tax benefits appears to be little related to intrinsic social preferences. Above, we have already provided evidence that tax benefits may give an incentive to hold SRI funds also for investors without strong social motivations for reasons of higher expected net-returns.

In this section, we take a closer look at reputation as a possible motive to buy socially responsible mutual funds. As pro-sociality is commonly valued positively in society, investors without strong intrinsic social preferences who nevertheless hold SRI funds may use these investments as a signal of their prosocial personality. Consequently, a hypothesis that can be tested is that SR investors with stronger intrinsic social preferences are less likely to use SRI is a signaling tool. 
We do not have data with which we could directly measure such reputation concerns but need to resort to a proxy. Recall, that investors in our dataset buy funds directly online without interference of an intermediary. Hence, if investors want to benefit from SRI funds as a signal for prosocial reputation they need to communicate it to others in one or the other way. In the survey, investors reported on how often they communicate about their investments by indicating their (dis)agreement with the statement "I often talk about investments to others." on a 1-7 scale. We use answers to this question as our proxy. $^{18}$

\section{<INSERT TABLE 7 ABOUT HERE>}

Table 7 presents OLS regressions where only socially responsible investors are considered. The dependent variable represents the ratings of the extent to which socially responsible investors agree to the statement above. The results show that a one point higher return ratio in the trust game is associated with a 0.462 point decrease in the agreement to the statement above $(\mathrm{p}=0.024)$. This implies that among SR investors those with weaker social preferences indeed talk more about investments and, hence, probably benefit more from signaling benefits.

We hasten to note that we are aware of the many potential reasons for people to talk about their investments. Therefore, we view the presented evidence only as suggestive although such communication certainly is a necessary condition to signal prosocial behavior. Future research has to show the robustness of this result.

\section{Conclusion}

This paper shows that investors with stronger social preferences are more likely to hold SRI mutual funds without tax incentives. We use an anonymous experiment that rules out

18 This question was asked at the beginning of the survey before any question on prosocial behavior. At that stage of the survey, no reference to socially responsible investments had been made yet. 
reputation concerns as an explanation for prosocial behavior. The finding that investments in SRI funds are largely driven by social preferences rather than return or risk expectations suggests that socially responsible investments can have long run effects on stock prices if the growth in SRI continues. Currently, there is only a robust effect found for the influence of social preferences on the stock prices of sin companies, driven by institutional investors (Hong and Kacperczyk, 2009). Stock prices of other types of socially responsible companies such as green companies and fair trade companies could be affected in the long run if the proportion of SR investors in the market will increase.

More broadly, our paper shows that individuals who behave prosocially in one domain (the trust game) also behave more prosocially in another domain (socially responsible investments). Previous evidence on the stability of social preferences over various domains is mixed (Karlan (2005), List (2006), Benz and Meier (2008), Falk and Heckman (2009), Baran, Sapienza and Zingales (2010), Stoop, Noussair and Van Soest (2012)). For instance, List (2006) finds that sports cards traders behave substantially different in gift exchange in the lab and in the field. Stoop, Noussair and Van Soest (2012) find that fishermen cooperate in a standard monetary voluntary contribution mechanism, but fish more than the social optimum in a field setting. In contrast, Karlan (2005) finds that Peruvian microfinance borrowers are more likely to repay their loans if they give back more in a trust game. Benz and Meier (2008) find that students who donate more in a lab also donate more outside of the lab. The relation we find between behavior in the experiment and in the field is rather conservative, because investors in our study were unaware that we matched their survey responses and experimental behavior to their (anonymized) trading records. This mitigates the potential problem that socially responsible investors want to behave consistently prosocially in the experiment (for evidence on consistency see for instance Gneezy et al. 2012). Our evidence shows that introducing extrinsic rewards such as tax benefits in the field eliminates the relation between prosocial field behavior and prosocial behavior in an experiment that has no extrinsic rewards to prosocial behavior. 
Our findings also have important practical consequences. First, banks and mutual fund providers can benefit from distinguishing between selfish and prosocial investors concerning their marketing strategies. The strong intrinsic motivation of many socially responsible investors might be undermined by advertisements that are focused too much on returns (Gneezy and Rustichini (2000a, b), Benabou and Tirole (2006)). In contrast, more selfish investors who hold SRI funds for reputation reasons might benefit from some signaling tools. Second, the Dutch government provides tax incentives on some types of SRI funds. Our findings suggest that intrinsic social preferences are unrelated to investments in these types of funds. In other words, these funds also attract selfish investors, which might reduce the amount invested socially responsible if the tax incentives decrease. In particular, because investors in SRI funds with tax benefits report good investment knowledge and might be well aware of outside investment opportunities. 


\section{References}

Ariely, D., A. Bracha and S. Meier, 2009, "Doing Good or Doing Well? Image Motivation and Monetary Incentives in Behaving Prosocially", American Economic Review, 99(1), 544-555.

Andreoni, J., 1990, "Impure Altruism and Donations to Public Goods: A Theory of Warm-Glow Giving", Economic Journal, 100(401), 464-477.

Baran, N. M., P. Sapienza and L. Zingales, 2010, "Can We Infer Social Preferences from the Lab? Evidence from the Trust Game", NBER Working Papers, 15654.

Bauer, R., R. Otten and K. Koedijk, 2005, "International evidence on ethical mutual fund performance and investment style", Journal of Banking and Finance, 29(7), 17511767.

Benabou, R. and J. Tirole, 2006, "Incentives and Prosocial Behavior", American Economic Review, 96(5), 1652-1678.

Benz, M. and S. Meier, 2008, "Do People Behave in Experiments as in the Field? Evidence from Donations", Experimental Economics, 11(3), 268-281.

Berg, J., J. Dickhaut and K. McCabe, 1995, "Trust, Reciprocity and Social History", Games and Economic Behaviour, 10(1), 122-142.

Bollen, N., 2007, "Mutual Fund Attributes and Investor Behavior", Journal of Financial and Quantitative Analysis, 42(3), 683-708.

Bolton, G. E., and A. Ockenfels, 2000, "ERC: A Theory of Equity, Reciprocity, and Competition", American Economic Review, 90(1), 166-193.

Calvet, L., J. Campbell and P. Sodini, 2009, "Measuring the Financial Sophistication of Households", American Economic Review, 99(2), 393-398.

Cohen, L., 2009, "Loyalty-Based Portfolio Choice", Review of Financial Studies, 22(3), 1213-1245.

Coval, J. and T. Moskowitz, 1999, "Home Bias at Home: Local Equity Preference in Domestic Portfolios", Journal of Finance, 54(6), 2045-2073.

Croson, R. and U. Gneezy, 2009, "Gender Differences in Preferences", Journal of Economic Literature, 47(2), 1-27.

Derwall, J., K. Koedijk and J. Ter Horst, 2011, "A Tale of Values-Driven and ProfitSeeking Social Investors", Journal of Banking and Finance, 35(8), 2137-2147.

Derwall, J., N. Guenster, R. Bauer and K. Koedijk, 2005, "The Eco-Efficiency Premium Puzzle", Financial Analysts Journal, 61(2), 51-63. 
Dohmen, T., A. Falk, D. Huffmann, J. Schupp, U. Sunde and G. G. Wagner, 2011, "Individual Risk Attitudes: Measurement, Determinants and Behavioural Consequences", Journal of the European Economics Association, 9(3), 522-550.

Dorn, D. and G. Huberman, 2005, "Talk and action: What Individual Investors Say and What They Do", Review of Finance, 9(4), 437-481.

Edmans, A., 2011, "Does the Stock Market Fully Value Intangibles? Employee Satisfaction and Equity Prices", Journal of Financial Economics, 101(3), 621640.

Egas, M. and Arno Riedl, 2008, "The Economics of Altruistic Punishment and the Maintenance of Cooperation", Proceedings of the Royal Society B: Biological Sciences, 275, 871-878.

EUROSIF, 2012, European SRI study 2012, http://www.eurosif.org.

Fabozzi, F.J. K.C. Ma and B.J. Oliphant, 2008, "Sin stock returns", Journal of Portfolio Management, 82-74.

Falk, A. and J. J. Heckmann, 2009, "Lab Experiments are a Major Source of Knowledge in the Social Sciences", Science, 326(5952), 535-538.

Falk, A., S. Meier and C. Zehnder, 2012, "Do Lab Experiments Misrepresent Social Preferences? The Case of Self-Selected Student Samples", Journal of the European Economic Association, forthcoming.

Falk, A., and C. Zehnder, 2007, "Discrimination and In-Group Favouritism in a Citywide Trust Experiment", Working paper.

Fehr, E., and S. Gächter, 2000, "Cooperation and punishment in public goods experiments", American Economic Review, 90(4), 980-994.

Fehr, E. and J. A. List, 2004, "The Hidden Costs and Returns of Incentives - Trust and Trust-worthiness Among CEO's", Journal of the European Economic Association, 2(5), 743-771.

Fehr, E. and K. M. Schmidt, 1999, "A Theory of Fairness, Competition and Cooperation, Quarterly Journal of Economics, 114 (3), 817-868.

Gneezy, U. and A. Rustichini, 2000a, "Pay Enough or Don’t Pay at All", Quarterly Journal of Economics, 115(3), 791-810.

Gneezy, U. and A. Rustichini, 2000b, “A Fine Is a Price”, Journal of Legal Studies, 29(1), $1-17$.

Gneezy, A., A. Imas, L. D. Nelson, A. Brown and M. I. Norton, 2012, "Paying to Be Nice: Consistency and Costly Prosocial Behaviour", Management Science, 58(1), 179-187. 
Graham, J. R., C. R. Harvey and H. Huang, 2009, "Investor Competence, Trading Frequency, and Home Bias", Management Science, 55(7), 1094-1106.

Holt, C. A. and S. K. Laury, 2002, "Risk Aversion and Incentive Effects", American Economic Review 92(5), 1644-1655.

Hong, H., and M. Kacperczyk, 2009, "The Price of Sin: The Effects of Social Norms on Markets." Journal of Financial Economics, 93(1), 15-36.

Hong, H., and L. Kostovetsky, 2012, "Red and Blue Investing: Values and Finance", Journal of Financial Economics, 103(1), 1-19.

Hong, H. and J. Stein, 2007, "Disagreement and the Stock Market", Journal of Economic Perspectives, 21(2), 109-128.

Ivkovic, Z. and S. Weisbenner, 2005, "Local Does as Local is: Information Content of the Geography of Individual Investors' Common Stock Investments", Journal of Finance, 60(1), 267-306.

Karlan, D. S., 2005, "Using Experimental Economics to Measure Social Capital and Predict Financial Decisions", American Economic Review, 95(5), 1688-1699.

Kaustia, M., and S. Torstila, 2011, "Stock Market Aversion? Political Preferences and Stock Market Participation.” Journal of Financial Economics, 100(1), 98-112.

Keloharju, M., S. Knüpfer and J. T. Linnainmaa, 2012, "Do Investors Buy What They Know? Product Market Choices and Investment Decisions", Review of Financial Studies, 25(10), 2921-2958.

Kempf, A., Osthoff, P., 2007. The Effect of Socially Responsible Investing on Portfolio Performance. European Financial Management 13, 908-922.

Kreps, D.M., P. Milgrom, J. Roberts and R. Wilson, 1982, "Rational Cooperation in the Finitely Repeated Prisoners' Dilemma", Journal of Economic Theory, 27, 245252.

Kumar, A. and J. Page, 2011, "Deviations from norms and informed trading" Journal of Financial and Quantitative Analysis, forthcoming.

Ledyard, John, O., 1995, "Public Goods: A Survey of Experimental Research", in Handbook of Experimental Economics, edited by J. Kagel and A. Roth, Princeton University Press, 1995.

List, J. A., 2006, “The Behavioralist Meets the Market: Measuring Social Preferences and Reputation Effects in Actual Transactions", Journal of Political Economy, 114(1), $1-37$.

Millward Brown, 2011, Retail Investor 2011, Yearly publication. 
Pool, V., N. Stoffman and S. Yonker, 2012, "No Place Like Home: Familiarity in Mutual Fund Manager Portfolio Choice”, Review of Financial Studies, 25(8), 2563-2599

Renneboog, L, J. Ter Horst and C. Zhang, 2008, "The Price of Ethics and Stakeholder governance: The performance of socially responsible mutual funds", Journal of Corporate Finance, 14(3), 302-322

Selten, R., 1967, "Die Strategiemethode zur Erforschung des Eingeschränkt Rationalen Verhaltens in Rahmen Eines Oligopolexperiments" in Sauerman, H. (ed), "Beiträge Zur Experimentellen Wirtschaftsforschung", Tübingen: J.C.B., Mohr (Paul Siebeck).

SIF (Social Investment Forum), 2012, Report on Socially Responsible Investing Trends in the United States, http://www.socialinvest.org.

Sobel, J., 2005, "Interdependent Preferences and Reciprocity", Journal of Economic Literature, 43(2), 392-436.

Stoop, J.T.R., Ch.N. Noussair and D.P. van Soest, 2012, "From the Lab to the Field: Cooperation Among Fishermen", Journal of Political Economy, forthcoming.

Van Rooij, M., A. Lusardi, R. Alessie, 2011, "Financial Literacy and Stock Market Participation", Journal of Financial Economics, 101(2), 449-472. 
Tables

Table 1 - Variable definitions

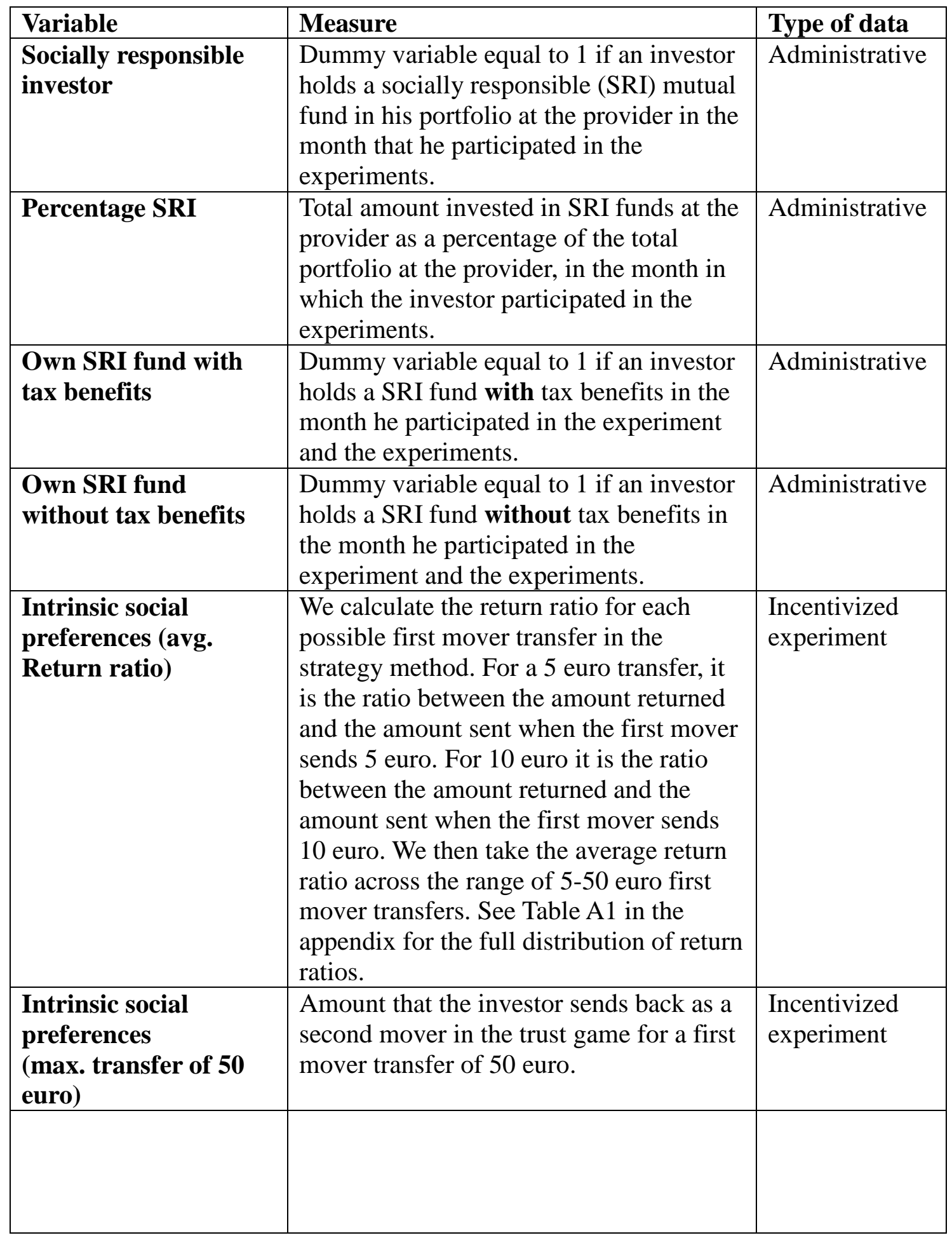




\begin{tabular}{|c|c|c|}
\hline Expected return SRI & $\begin{array}{l}\text { I expect that the returns of socially } \\
\text { responsible equity funds compared to } \\
\text { conventional equity funds are: } \\
\text { - Much lower } \\
\text { - A bit lower } \\
\text { - The same } \\
\text { - A bit higher } \\
\text { - Much higher } \\
\text { - I do not know } \\
\end{array}$ & Survey \\
\hline Perceived risk on SRI & $\begin{array}{l}\text { Socially responsible equity funds are } \\
\text { more risky than conventional equity } \\
\text { funds (fully disagree } 1-7 \text { fully agree) }\end{array}$ & Survey \\
\hline $\begin{array}{l}\text { Lower expected } \\
\text { return on SRI }\end{array}$ & $\begin{array}{l}\text { Dummy equal to } 1 \text { if an investor believes } \\
\text { that the returns on SRI equity funds are } \\
\text { lower than on conventional equity funds. }\end{array}$ & Survey \\
\hline $\begin{array}{l}\text { Lower perceived risk } \\
\text { on SRI }\end{array}$ & $\begin{array}{l}\text { Dummy equal to } 1 \text { if an investor } \\
\text { perceives the risk on SRI equity funds to } \\
\text { be lower than the risk of conventional } \\
\text { equity funds. }\end{array}$ & \\
\hline Total Portfolio Value & $\begin{array}{l}\text { Total euro amount invested at the } \\
\text { provider in the month that the investor } \\
\text { participated in the experiments. }\end{array}$ & Administrative \\
\hline Investment knowledge & $\begin{array}{l}\text { My investment knowledge is good (fully } \\
\text { disagree 1-7 fully agree) }\end{array}$ & Survey \\
\hline Risk preferences & $\begin{array}{l}\text { Amount at which the investor switches } \\
\text { from choosing the risky lottery to } \\
\text { choosing the risk-free option in the risk } \\
\text { preference task. }\end{array}$ & $\begin{array}{l}\text { Incentivized } \\
\text { experiment }\end{array}$ \\
\hline Low income & $\begin{array}{l}\text { Gross family income is below } 60,000 \\
\text { euro per year }\end{array}$ & Survey \\
\hline Medium income & $\begin{array}{l}\text { Gross family income is between } 60,000 \\
\text { euro and } 100,000 \text { euro per year }\end{array}$ & Survey \\
\hline High income & $\begin{array}{l}\text { Gross income is above } 100,000 \text { euro per } \\
\text { year }\end{array}$ & Survey \\
\hline Untold income & The investor does not disclose his income & Survey \\
\hline $\begin{array}{l}\text { Talk about } \\
\text { investments }\end{array}$ & $\begin{array}{l}\text { I often talk about investment with others } \\
\text { (fully disagree 1-7 fully agree) }\end{array}$ & Survey \\
\hline $\begin{array}{l}\text { Mean portfolio } \\
\text { returns }\end{array}$ & $\begin{array}{l}\text { Average monthly portfolio returns since } \\
\text { the investor opened her account }\end{array}$ & Administrative \\
\hline $\begin{array}{l}\text { St. Dev. monthly } \\
\text { portfolio returns }\end{array}$ & $\begin{array}{l}\text { Standard deviation of the monthly } \\
\text { portfolio returns since the investor } \\
\text { opened her account }\end{array}$ & Administrative \\
\hline
\end{tabular}




\section{Table 2 - Summary statistics}

This table presents background information from the transaction data on the portfolios of socially responsible and conventional investors. The statistics represent the portfolios of investors in the month in which they participated in the experiment and the survey.

Panel A - Portfolios of socially responsible investors (14\% of the sample)

\begin{tabular}{|l|c|}
\hline $\begin{array}{l}\text { Percentage SRI in total } \\
\text { portfolio }\end{array}$ & $14.9 \%$ \\
\hline $\begin{array}{l}\text { Only hold SRI with tax } \\
\text { benefits }\end{array}$ & $19.5 \%$ \\
\hline $\begin{array}{l}\text { Only hold SRI without } \\
\text { tax benefits }\end{array}$ & $68.4 \%$ \\
\hline $\begin{array}{l}\text { Hold both SRI with and } \\
\text { without tax benefits }\end{array}$ & $12.1 \%$ \\
\hline
\end{tabular}




\section{Panel B - Comparison socially responsible and conventional investors}

This table presents the summary statistics for socially responsible and conventional investors separately. All variables are defined in Table 1. Standard deviations are in parentheses. P-values are from Mann-Whitney tests.

\begin{tabular}{|c|c|c|c|c|c|c|c|}
\hline & \multicolumn{3}{|c|}{$\begin{array}{l}\text { Socially responsible investors } \\
(14 \%)\end{array}$} & \multicolumn{3}{|c|}{$\begin{array}{c}\text { Conventional investors } \\
(\mathbf{8 6 \%})\end{array}$} & \multirow[b]{2}{*}{$\mathbf{P}$} \\
\hline & Mean & Median & $\mathbf{N}$ & Mean & Median & $\mathbf{N}$ & \\
\hline $\begin{array}{l}\text { Intrinsic social preferences } \\
\text { (Avg. Return ratio) }\end{array}$ & $\begin{array}{r}1.5269 \\
(0.6695)\end{array}$ & 1.73 & 140 & $\begin{array}{r}1.4173 \\
(0.6749)\end{array}$ & 1.51 & 763 & 0.087 \\
\hline $\begin{array}{l}\text { Intrinsic social preferences } \\
\text { (Max. transfer of } 50 \text { euro) }\end{array}$ & $\begin{array}{r}77.4643 \\
(34.4927) \\
\end{array}$ & 100.00 & 140 & $\begin{array}{r}71.6121 \\
(34.8929) \\
\end{array}$ & 80.00 & 763 & 0.061 \\
\hline $\begin{array}{l}\text { Expected returns } \\
\text { on SRI }\end{array}$ & $\begin{array}{r}2.7055 \\
(1.0041)\end{array}$ & 2.00 & 506 & $\begin{array}{r}2.8206 \\
(1.3229)\end{array}$ & 2.00 & 2776 & 0.692 \\
\hline $\begin{array}{l}\text { Expected risk } \\
\text { on SRI }\end{array}$ & $\begin{array}{r}3.5377 \\
(1.2653)\end{array}$ & 4.00 & 504 & $\begin{array}{r}3.5742 \\
(1.2458)\end{array}$ & 4.00 & 2750 & 0.385 \\
\hline $\begin{array}{l}\text { Lower expected } \\
\text { returns on SRI }\end{array}$ & $\begin{array}{r}0.5193 \\
(0.5001) \\
\end{array}$ & 1.00 & 491 & $\begin{array}{r}0.5974 \\
(0.4905) \\
\end{array}$ & 1.00 & 2489 & 0.001 \\
\hline $\begin{array}{l}\text { Lower perceived } \\
\text { risk on SRI }\end{array}$ & $\begin{array}{r}0.4345 \\
(0.4962)\end{array}$ & 0.00 & 504 & $\begin{array}{r}0.3895 \\
(0.4877)\end{array}$ & 0.00 & 2750 & 0.057 \\
\hline $\begin{array}{l}\text { Total portfolio } \\
\text { Value }\end{array}$ & $\begin{array}{r}106677.80 \\
(190033.20)\end{array}$ & 57665.95 & 747 & $\begin{array}{r}73250.33 \\
(127344.30)\end{array}$ & 36495.54 & 4494 & 0.000 \\
\hline $\begin{array}{l}\text { Investment } \\
\text { knowledge }\end{array}$ & $\begin{array}{r}4.1916 \\
(1.3073) \\
\end{array}$ & 4.00 & 642 & $\begin{array}{r}3.8276 \\
(1.4734) \\
\end{array}$ & 4.00 & 3881 & 0.000 \\
\hline University degree & $\begin{array}{r}0.4990 \\
(0.5005) \\
\end{array}$ & 0.00 & 487 & $\begin{array}{r}0.4622 \\
(0.4987) \\
\end{array}$ & 0.00 & 2609 & 0.136 \\
\hline Risk preferences & $\begin{array}{r}113.2909 \\
(41.5708) \\
\end{array}$ & 110.00 & 550 & $\begin{array}{r}112.2275 \\
(42.8290) \\
\end{array}$ & 110.00 & 3129 & 0.723 \\
\hline Female & $\begin{array}{r}0.1810 \\
(0.3852) \\
\end{array}$ & 0.00 & 746 & $\begin{array}{r}0.2094 \\
(0.4069) \\
\end{array}$ & 0.00 & 4585 & 0.075 \\
\hline Age & $\begin{array}{r}57.7542 \\
(12.1359) \\
\end{array}$ & 57.00 & 716 & $\begin{array}{r}59.1040 \\
(11.6319) \\
\end{array}$ & 59.00 & 4377 & 0.002 \\
\hline Low income & $\begin{array}{r}0.3223 \\
(0.4678) \\
\end{array}$ & 0.00 & 484 & $\begin{array}{r}0.3228 \\
(0.4676) \\
\end{array}$ & 0.00 & 2590 & 0.984 \\
\hline High income & $\begin{array}{r}0.2087 \\
(0.4068) \\
\end{array}$ & 0.00 & 484 & $\begin{array}{r}0.1965 \\
(0.3974) \\
\end{array}$ & 0.00 & 2590 & 0.538 \\
\hline Untold income & $\begin{array}{r}0.1798 \\
(0.3844)\end{array}$ & 0.00 & 484 & $\begin{array}{r}0.1772 \\
(0.3819) \\
\end{array}$ & 0.00 & 2590 & 0.894 \\
\hline $\begin{array}{l}\text { Talk about investments } \\
(1-7)\end{array}$ & $\begin{array}{r}3.1122 \\
(1.5123) \\
\end{array}$ & 3 & 642 & $\begin{array}{r}2.9093 \\
(1.5217) \\
\end{array}$ & 3 & 3881 & 0.001 \\
\hline
\end{tabular}




\section{Table 3 - Likelihood to own a SRI fund}

This table presents marginal effects of probit regressions in which the dependent variable takes on the value of 1 if an investor holds a SRI mutual fund in the month that he participated in the experiment and survey. In the first specification 'Intrinsic social preferences' is the average return ratio across all possible first mover transfers from 5 euro through 50 euro. In the second specification 'Intrinsic social preferences' is the amount returned by the second mover in the strategy method trust game in units of 10 euro for a maximum transfer of the first mover of 50 euro. All other variables are defined in Table 1 . Standard errors are in parentheses. * is $10 \% * *$ is $5 \%$ and $* * *$ is $1 \%$ significance.

\begin{tabular}{|c|c|c|}
\hline & $\begin{array}{l}\text { Avg. Return Ratio } \\
\text { (1) }\end{array}$ & $\begin{array}{c}\text { Max. Transfer of } 50 \text { Euro } \\
(2)\end{array}$ \\
\hline \multicolumn{3}{|l|}{ PREFERENCES } \\
\hline Intrinsic social preferences & $\begin{array}{l}0.0405^{* *} \\
(0.0205)\end{array}$ & $\begin{array}{l}0.0080^{* *} \\
(0.0040)\end{array}$ \\
\hline \multicolumn{3}{|l|}{ BELIEFS } \\
\hline $\begin{array}{l}\text { Lower expected returns on } \\
\text { SRI }\end{array}$ & $\begin{array}{l}-0.0295 \\
(0.0271)\end{array}$ & $\begin{array}{l}-0.0295 \\
(0.0271)\end{array}$ \\
\hline $\begin{array}{l}\text { Lower perceived risk on } \\
\text { SRI }\end{array}$ & $\begin{array}{l}-0.0257 \\
(0.0267)\end{array}$ & $\begin{array}{l}-0.0253 \\
(0.0267)\end{array}$ \\
\hline \multicolumn{3}{|l|}{ CONTROLS } \\
\hline Log total portfolio value & $\begin{array}{c}0.0431 * * * \\
(0.0098)\end{array}$ & $\begin{array}{c}0.0427 * * * \\
(0.0098)\end{array}$ \\
\hline Investment knowledge & $\begin{array}{l}0.0189 * \\
(0.0107)\end{array}$ & $\begin{array}{l}0.0186^{*} \\
(0.0107)\end{array}$ \\
\hline University degree & $\begin{array}{c}0.0390 \\
(0.0281)\end{array}$ & $\begin{array}{c}0.0383 \\
(0.0281)\end{array}$ \\
\hline Risk preferences & $\begin{array}{l}-0.0003 \\
(0.0003)\end{array}$ & $\begin{array}{l}-0.0003 \\
(0.0003)\end{array}$ \\
\hline Female & $\begin{array}{l}-0.0447 \\
(0.0336)\end{array}$ & $\begin{array}{l}-0.0446 \\
(0.0337)\end{array}$ \\
\hline Age & $\begin{array}{l}-0.0021 \\
(0.0013)\end{array}$ & $\begin{array}{l}-0.0021 \\
(0.0013)\end{array}$ \\
\hline Low income & $\begin{array}{c}0.0299 \\
(0.0361)\end{array}$ & $\begin{array}{c}0.0296 \\
(0.0361)\end{array}$ \\
\hline High income & $\begin{array}{l}-0.0411 \\
(0.0347) \\
\end{array}$ & $\begin{array}{l}-0.0412 \\
(0.0347)\end{array}$ \\
\hline Untold income & $\begin{array}{c}0.0157 \\
(0.0416)\end{array}$ & $\begin{array}{c}0.0154 \\
(0.0416)\end{array}$ \\
\hline Base probability & 0.1574 & 0.1574 \\
\hline $\mathrm{N}$ & & \\
\hline Pseudo R2 & 0.0522 & 0.0525 \\
\hline
\end{tabular}




\section{Table 4 - Percentage invested in SRI funds}

This table presents marginal effects of tobit regressions in which the dependent variable is the percentage of the portfolio that is held in SRI mutual fund in the month that he participated in the experiment and survey. The regressions account for left-censoring at $0 \%$ and right-censoring at $100 \%$. In the first specification 'Intrinsic social preferences' is the average return ratio across all possible first mover transfers from 5 euro through 50 euro. In the second specification 'Intrinsic social preferences' is the amount returned by the second mover in the strategy method trust game in units of 10 euro for a maximum transfer of the first mover of 50 euro. All other variables are defined in Table 1. Standard errors are in parentheses. $*$ is $10 \% * *$ is $5 \%$ and $* * *$ is $1 \%$ significance.

\begin{tabular}{|c|c|c|}
\hline & $\begin{array}{l}\text { Avg. Return Ratio } \\
\text { (1) }\end{array}$ & $\begin{array}{c}\text { Max. Transfer of } 50 \text { Euro } \\
\text { (2) }\end{array}$ \\
\hline \multicolumn{3}{|l|}{ PREFERENCES } \\
\hline $\begin{array}{l}\text { Intrinsic social } \\
\text { preferences }\end{array}$ & $\begin{array}{l}5.4702 * * \\
(2.8058) \\
\end{array}$ & $\begin{array}{r}1.0537 * \\
(0.5457) \\
\end{array}$ \\
\hline \multicolumn{3}{|l|}{ BELIEFS } \\
\hline $\begin{array}{l}\text { Lower expected returns } \\
\text { on SRI }\end{array}$ & $\begin{array}{l}-3.7611 \\
(3.6141)\end{array}$ & $\begin{array}{l}-3.7700 \\
(3.6167) \\
\end{array}$ \\
\hline $\begin{array}{l}\text { Lower perceived risk on } \\
\text { SRI }\end{array}$ & $\begin{array}{l}-2.7315 \\
(3.6567) \\
\end{array}$ & $\begin{array}{l}-2.6571 \\
(3.6573) \\
\end{array}$ \\
\hline \multicolumn{3}{|l|}{ CONTROLS } \\
\hline Log total portfolio value & $\begin{array}{l}3.3022 * * \\
(1.3089)\end{array}$ & $\begin{array}{l}3.2438 * * \\
(1.3044)\end{array}$ \\
\hline Investment knowledge & $\begin{array}{c}1.2730 \\
(1.4460)\end{array}$ & $\begin{array}{c}1.2208 \\
(1.4462)\end{array}$ \\
\hline University degree & $\begin{array}{l}7.2647 * \\
(3.7926) \\
\end{array}$ & $\begin{array}{l}7.1795^{*} \\
(3.7957) \\
\end{array}$ \\
\hline Risk preferences & $\begin{array}{l}-0.0251 \\
(0.0459) \\
\end{array}$ & $\begin{array}{l}-0.0257 \\
(0.0459) \\
\end{array}$ \\
\hline Female & $\begin{array}{l}-6.6990 \\
(5.2547)\end{array}$ & $\begin{array}{l}-6.7225 \\
(5.2625)\end{array}$ \\
\hline Age & $\begin{array}{l}-0.2787 \\
(0.1785)\end{array}$ & $\begin{array}{l}-0.2795 \\
(0.1786)\end{array}$ \\
\hline Low income & $\begin{array}{c}6.6228 \\
(4.6470)\end{array}$ & $\begin{array}{c}6.5796 \\
(4.6497) \\
\end{array}$ \\
\hline High income & $\begin{array}{l}-4.6530 \\
(5.2908)\end{array}$ & $\begin{array}{l}-4.6597 \\
(5.2907)\end{array}$ \\
\hline Untold income & $\begin{array}{c}4.8875 \\
(5.3374)\end{array}$ & $\begin{array}{c}4.8665 \\
(5.3398)\end{array}$ \\
\hline Constant & $\begin{array}{c}-64.1831 * * * \\
(18.4161)\end{array}$ & $\begin{array}{c}-63.0121 * * * \\
(18.2459)\end{array}$ \\
\hline $\mathrm{N}$ & & \\
\hline Pseudo R2 & 0.0137 & 0.0137 \\
\hline
\end{tabular}


Table 5 - Probability to invest in a SRI fund with tax benefits and without tax benefits

This table presents relative-risk ratios of a multinomial logit regression in which the dependent variable can take on four different values. The baseline group (not reported) is conventional investors, the second group is investors who only hold a SRI fund with tax benefits, the third only holds SRI fund without tax benefits and the fourth holds both types of SRI funds. 'Intrinsic social preferences' is the average return ratio across all possible first mover transfers from 5 euro through 50 euro. All other variables are defined in Table 1. Standard errors are in parentheses. * is $10 \% * *$ is $5 \%$ and $* * *$ is $1 \%$ significance.

\begin{tabular}{|c|c|c|c|}
\hline Only SRI funds & $\begin{array}{c}\text { with tax benefits } \\
\text { (1) }\end{array}$ & $\begin{array}{c}\text { without tax benefits } \\
\text { (2) }\end{array}$ & $\begin{array}{l}\text { with and without } \\
\text { tax benefits (3) }\end{array}$ \\
\hline \multicolumn{4}{|l|}{ PREFERENCES } \\
\hline $\begin{array}{l}\text { Intrinsic social } \\
\text { preferences }\end{array}$ & $\begin{array}{r}0.8089 \\
(0.2717) \\
\end{array}$ & $\begin{array}{l}1.4791 * * \\
(0.2626)\end{array}$ & $\begin{array}{c}1.9400 \\
(1.0638)\end{array}$ \\
\hline \multicolumn{4}{|l|}{ BELIEFS } \\
\hline $\begin{array}{l}\text { Lower expected } \\
\text { returns on SRI }\end{array}$ & $\begin{array}{c}1.4309 \\
(0.7585)\end{array}$ & $\begin{array}{c}0.7319 \\
(0.1612)\end{array}$ & $\begin{array}{c}0.5519 \\
(0.3549)\end{array}$ \\
\hline $\begin{array}{l}\text { Lower perceived } \\
\text { risk on SRI }\end{array}$ & $\begin{array}{c}1.5537 \\
(0.7548) \\
\end{array}$ & $\begin{array}{c}0.6964 \\
(0.1571) \\
\end{array}$ & $\begin{array}{c}1.2696 \\
(0.8042) \\
\end{array}$ \\
\hline \multicolumn{4}{|l|}{ CONTROLS } \\
\hline $\begin{array}{l}\text { Log total portfolio } \\
\text { value }\end{array}$ & $\begin{array}{l}1.6691 * * \\
(0.3661)\end{array}$ & $\begin{array}{c}1.2953 * * * \\
(0.1078) \\
\end{array}$ & $\begin{array}{c}2.2811 * * * \\
(0.7337)\end{array}$ \\
\hline $\begin{array}{l}\text { Investment } \\
\text { knowledge }\end{array}$ & $\begin{array}{l}1.8387 * * * \\
(0.4252)\end{array}$ & $\begin{array}{c}1.0812 \\
(0.0942)\end{array}$ & $\begin{array}{c}1.1280 \\
(0.2629)\end{array}$ \\
\hline University degree & $\begin{array}{c}0.4103 \\
(0.2275) \\
\end{array}$ & $\begin{array}{c}1.4316 \\
(0.3346) \\
\end{array}$ & $\begin{array}{l}4.6472 * \\
(3.8557)\end{array}$ \\
\hline Risk preferences & $\begin{array}{c}0.9954 \\
(0.0058)\end{array}$ & $\begin{array}{c}0.9986 \\
(0.0028)\end{array}$ & $\begin{array}{c}0.9964 \\
(0.0087)\end{array}$ \\
\hline Female & $\begin{array}{c}0.6815 \\
(0.5361)\end{array}$ & $\begin{array}{l}0.5262 * \\
(0.1891)\end{array}$ & $\begin{array}{c}2.9819 \\
(2.0591)\end{array}$ \\
\hline Age & $\begin{array}{c}1.0287 \\
(0.0247)\end{array}$ & $\begin{array}{l}0.9792 * \\
(0.0108)\end{array}$ & $\begin{array}{c}0.9556 \\
(0.0321)\end{array}$ \\
\hline Low income & $\begin{array}{l}1.0665 \\
(0.6420)\end{array}$ & $\begin{array}{c}1.2132 \\
(0.3502)\end{array}$ & $\begin{array}{c}1.9843 \\
(1.5460)\end{array}$ \\
\hline High income & $\begin{array}{c}0.0000 \\
(0.0004)\end{array}$ & $\begin{array}{c}0.9170 \\
(0.2833)\end{array}$ & $\begin{array}{c}0.2401 \\
(0.2763)\end{array}$ \\
\hline Untold income & $\begin{array}{c}1.1449 \\
(0.7617)\end{array}$ & $\begin{array}{c}1.0630 \\
(0.3528) \\
\end{array}$ & $\begin{array}{c}0.8343 \\
(0.7622)\end{array}$ \\
\hline $\mathrm{N}$ & & 764 & \\
\hline Pseudo R2 & & 0.0916 & \\
\hline
\end{tabular}


Table 6 - Controlling for portfolio returns and standard deviations

This table presents relative-risk ratios of a multinomial logit regression in which the dependent variable can take on four different values. The baseline group (not reported) is conventional investors, the second group is investors who only hold a SRI fund with tax benefits, the third only holds SRI fund without tax benefits and the fourth holds both types of SRI funds. 'Intrinsic social preferences' is the average return ratio across all possible first mover transfers from 5 euro through 50 euro. All other variables are defined in Table 1. Standard errors are in parentheses. * is $10 \% * *$ is $5 \%$ and $* * *$ is $1 \%$ significance.

\begin{tabular}{|c|c|c|c|}
\hline Only SRI funds & $\begin{array}{c}\text { with tax benefits } \\
(1)\end{array}$ & $\begin{array}{c}\text { without tax benefits } \\
(2)\end{array}$ & $\begin{array}{l}\text { with and without } \\
\text { tax benefits (3) }\end{array}$ \\
\hline \multicolumn{4}{|l|}{ PREFERENCES } \\
\hline $\begin{array}{l}\text { Intrinsic social } \\
\text { preferences }\end{array}$ & $\begin{array}{c}0.7985 \\
(0.2734) \\
\end{array}$ & $\begin{array}{l}1.4759 * * \\
(0.2621)\end{array}$ & $\begin{array}{c}1.9164 \\
(1.0580) \\
\end{array}$ \\
\hline \multicolumn{4}{|l|}{ BELIEFS } \\
\hline $\begin{array}{l}\text { Lower expected } \\
\text { returns on SRI }\end{array}$ & $\begin{array}{c}1.6320 \\
(0.8816)\end{array}$ & $\begin{array}{c}0.7302 \\
(0.1612)\end{array}$ & $\begin{array}{c}0.5236 \\
(0.3408)\end{array}$ \\
\hline $\begin{array}{l}\text { Lower perceived risk } \\
\text { on SRI }\end{array}$ & $\begin{array}{c}1.7162 \\
(0.8639)\end{array}$ & $\begin{array}{c}0.6911 \\
(0.1563)\end{array}$ & $\begin{array}{c}1.2474 \\
(0.7912)\end{array}$ \\
\hline \multicolumn{4}{|l|}{ CONTROLS } \\
\hline $\begin{array}{l}\text { Monthly portfolio } \\
\text { returns }\end{array}$ & $\begin{array}{l}0.3140 * * * \\
(0.1370)\end{array}$ & $\begin{array}{c}1.0587 \\
(0.2120) \\
\end{array}$ & $\begin{array}{c}2.0373 \\
(1.3918) \\
\end{array}$ \\
\hline $\begin{array}{l}\text { St. Dev. monthly } \\
\text { portfolio returns }\end{array}$ & $\begin{array}{c}0.8721 \\
(0.1158) \\
\end{array}$ & $\begin{array}{c}1.0395 \\
(0.0486) \\
\end{array}$ & $\begin{array}{c}1.0707 \\
(0.1370) \\
\end{array}$ \\
\hline $\begin{array}{l}\text { Log total portfolio } \\
\text { value }\end{array}$ & $\begin{array}{l}1.6762 * * \\
(0.3805)\end{array}$ & $\begin{array}{l}1.2961 * * * \\
(0.1077)\end{array}$ & $\begin{array}{l}2.2590 * * \\
(0.7240)\end{array}$ \\
\hline $\begin{array}{l}\text { Investment } \\
\text { knowledge }\end{array}$ & $\begin{array}{l}2.0136^{* * * *} \\
(0.4868)\end{array}$ & $\begin{array}{c}1.0618 \\
(0.0955)\end{array}$ & $\begin{array}{c}1.0753 \\
(0.2591)\end{array}$ \\
\hline University degree & $\begin{array}{l}0.3647^{*} \\
(0.2064)\end{array}$ & $\begin{array}{l}1.4335 \\
(0.3363)\end{array}$ & $\begin{array}{l}4.9624 * \\
(4.1440)\end{array}$ \\
\hline Risk preferences & $\begin{array}{c}0.9958 \\
(0.0058) \\
\end{array}$ & $\begin{array}{c}0.9986 \\
(0.0028) \\
\end{array}$ & $\begin{array}{c}0.9964 \\
(0.0087) \\
\end{array}$ \\
\hline Female & $\begin{array}{c}0.6195 \\
(0.4908)\end{array}$ & $\begin{array}{l}0.5404^{*} \\
(0.1950)\end{array}$ & $\begin{array}{l}3.4751^{*} \\
(2.4993)\end{array}$ \\
\hline Age & $\begin{array}{c}1.0343 \\
(0.0251) \\
\end{array}$ & $\begin{array}{c}0.9789^{*} \\
(0.01085)\end{array}$ & $\begin{array}{c}0.9555 \\
(0.0322) \\
\end{array}$ \\
\hline Low income & $\begin{array}{c}1.0484 \\
(0.6286) \\
\end{array}$ & $\begin{array}{c}1.2316 \\
(0.3567) \\
\end{array}$ & $\begin{array}{c}1.9153 \\
(1.5119) \\
\end{array}$ \\
\hline High income & $\begin{array}{c}0.0000 \\
(0.0003)\end{array}$ & $\begin{array}{c}0.9113 \\
(0.2834)\end{array}$ & $\begin{array}{c}0.2284 \\
(0.2641)\end{array}$ \\
\hline Untold income & $\begin{array}{c}1.1603 \\
(0.7825) \\
\end{array}$ & $\begin{array}{c}1.0708 \\
(0.3555) \\
\end{array}$ & $\begin{array}{c}0.7215 \\
(0.6865) \\
\end{array}$ \\
\hline $\mathrm{N}$ & & 764 & \\
\hline Pseudo R2 & & 0.1010 & \\
\hline
\end{tabular}




\section{Table 7 - Intrinsic social preferences and reputation}

This table presents OLS regressions only for socially responsible investors. The dependent variable is the ratings of the agreement of socially responsible investors on a 1-7 Likert scale to the statement 'I often talk about investments to others.' Socially responsible investors who talk more about their investments with others can potentially gain more reputation benefits than socially responsible investors who cannot signal to others that they invest socially responsible. 'Intrinsic social preferences' is the average return ratio across all possible first mover transfers from 5 euro through 50 euro. All other variables are defined in Table 1. Standard errors are in parentheses. $*$ is $10 \% * *$ is $5 \%$ and $* * *$ is $1 \%$ significance.

\begin{tabular}{|c|c|}
\hline \multicolumn{2}{|l|}{ PREFERENCES } \\
\hline $\begin{array}{l}\text { Intrinsic social } \\
\text { preferences }\end{array}$ & $\begin{array}{c}-0.4618 * * \\
(0.2014) \\
\end{array}$ \\
\hline \multicolumn{2}{|l|}{ BELIEFS } \\
\hline $\begin{array}{l}\text { Lower expected returns } \\
\text { on SRI }\end{array}$ & $\begin{array}{c}0.0749 \\
(0.0955)\end{array}$ \\
\hline $\begin{array}{l}\text { Lower perceived risk on } \\
\text { SRI }\end{array}$ & $\begin{array}{c}0.1003 \\
(0.2720) \\
\end{array}$ \\
\hline \multicolumn{2}{|l|}{ CONTROLS } \\
\hline Log total portfolio value & $\begin{array}{l}-0.0114 \\
(0.1102)\end{array}$ \\
\hline Investment knowledge & $\begin{array}{c}0.4546 * * * \\
(0.1216)\end{array}$ \\
\hline University degree & $\begin{array}{c}0.0928 \\
(0.2725) \\
\end{array}$ \\
\hline Risk preferences & $\begin{array}{c}0.0032 \\
(0.0034)\end{array}$ \\
\hline Female & $\begin{array}{l}-0.0931 \\
(0.4034)\end{array}$ \\
\hline Age & $\begin{array}{l}-0.0009 \\
(0.0133)\end{array}$ \\
\hline Low income & $\begin{array}{l}-0.0894 \\
(0.3356)\end{array}$ \\
\hline High income & $\begin{array}{l}-0.4258 \\
(0.3894)\end{array}$ \\
\hline Untold income & $\begin{array}{l}-0.3076 \\
(0.3776)\end{array}$ \\
\hline Constant & $\begin{array}{c}1.5374 \\
(1.3416)\end{array}$ \\
\hline $\mathrm{N}$ & 132 \\
\hline R squared & 0.1718 \\
\hline
\end{tabular}




\section{Figures}

\section{Figure 1 - Return expectations of SRI funds}

This figure presents the separate distributions of return expectations for socially responsible and conventional investors. The variable 'Expected return SRI' depicts the response to the statement 'I expect that the returns of socially responsible equity funds compared to conventional equity funds are:' from 'much lower' to 'much higher'. The category 'I don't know' is excluded from the figure; it was chosen by $3 \%$ of the socially responsible and $10.3 \%$ of the conventional investors.

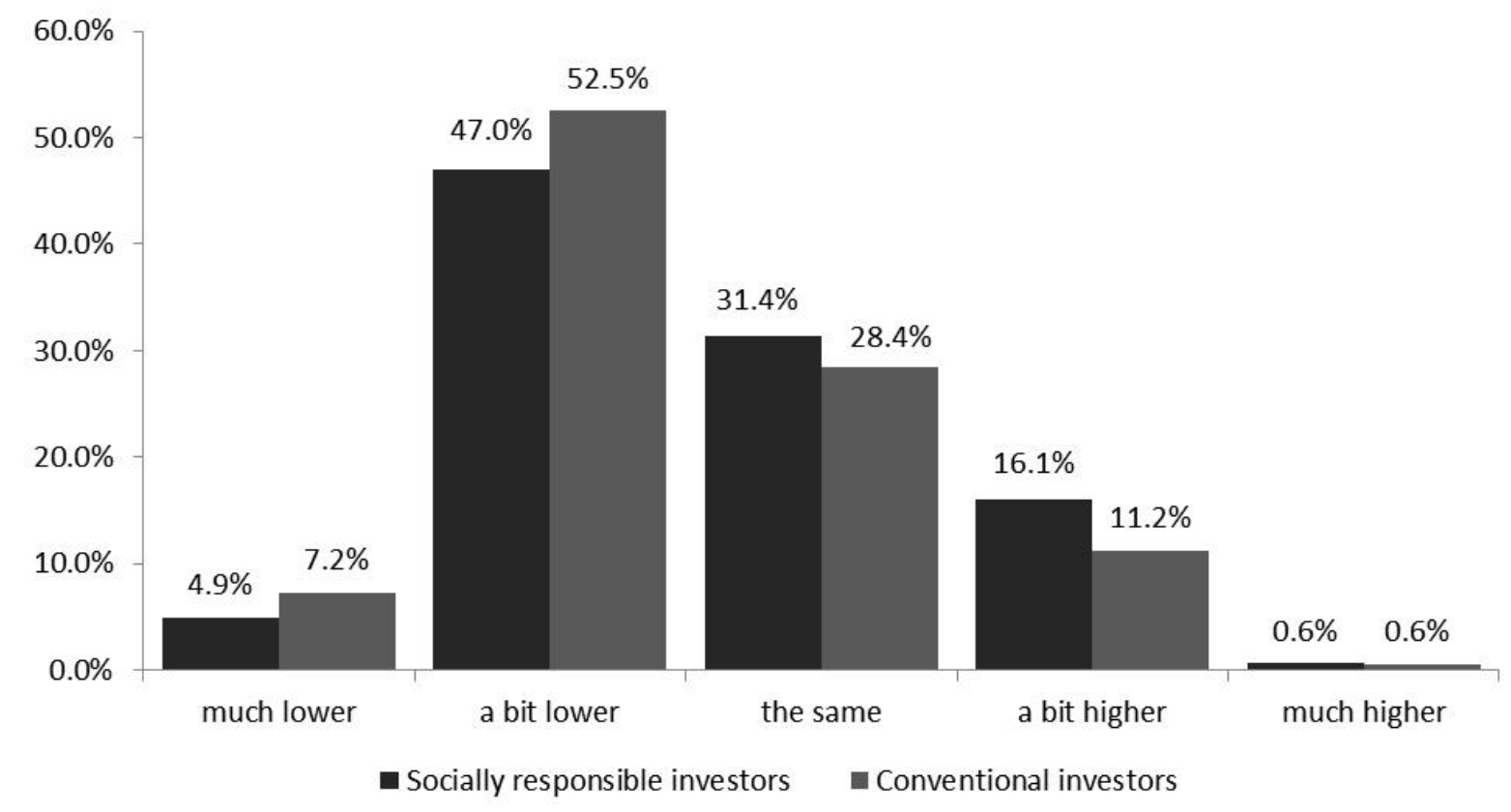




\section{Figure 2 - Risk perceptions of SRI funds}

This figure presents the separate distributions of risk perceptions of SRI funds for socially responsible and conventional investors. The variable 'Expected risk SRI' is the response of investors on a 1-7 Likert scale to the statement: "Socially responsible equity funds are more risky than conventional equity funds" where 1 is fully disagree and 7 fully agree.

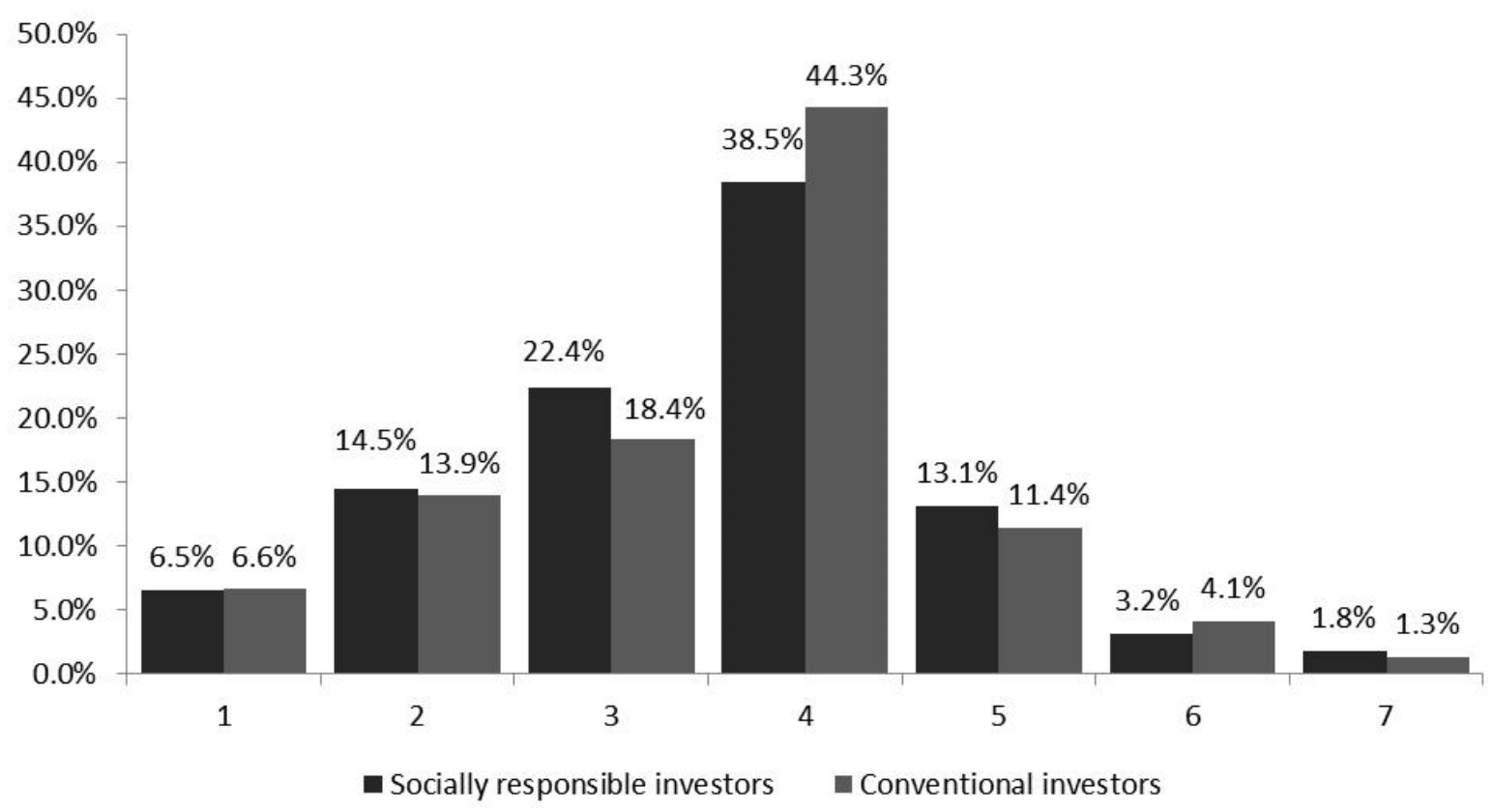




\section{Figure 3 - Intrinsic social preferences}

This figure shows the average return ratio for second-movers in the trust game for each possible positive transfer by the first mover. The average return ratio is calculated for socially responsible and conventional investors separately. We used the strategy method to elicit these return ratios as described in section 3.3. A return ratio of 1 means that the second mover sends back exactly the same amount as received by the first mover.

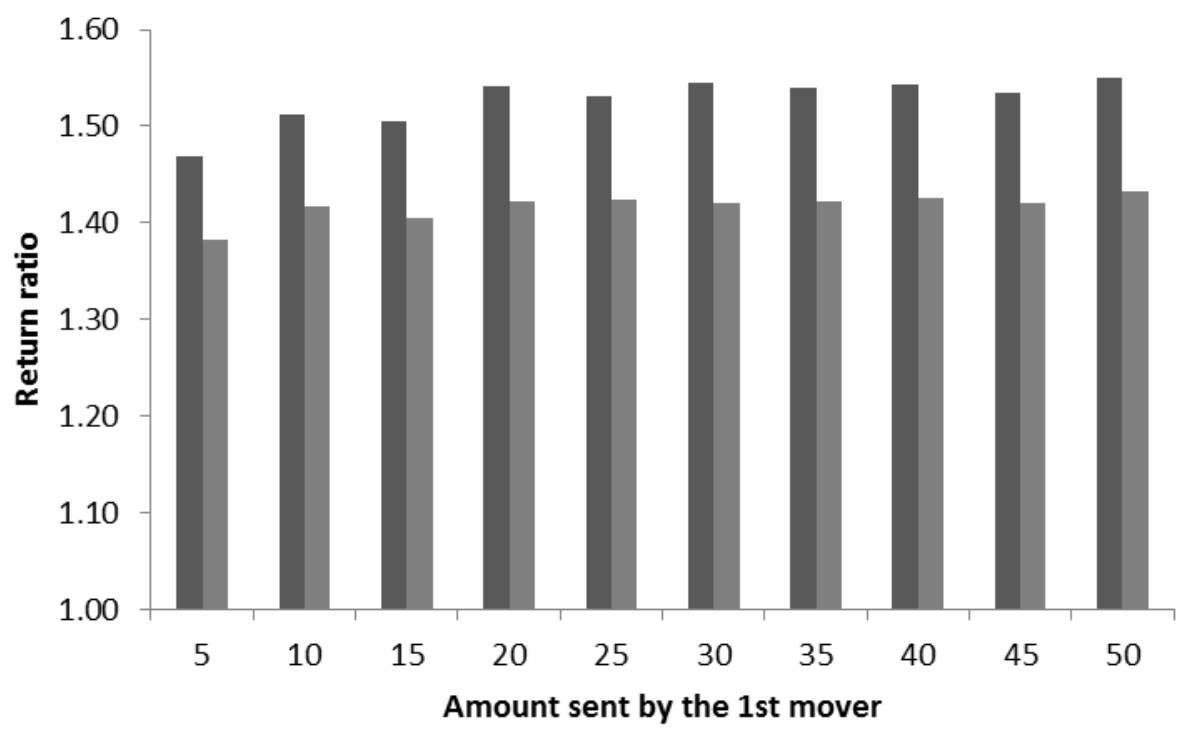

- Socially responsible investors $\quad$ Conventional investors 


\section{Figure 4 - Financial motives and portfolio choice}

To shed more light on the role of financial motivations on portfolio choice, we directly asked socially responsible investors why they invest in socially responsible mutual funds. The answer options are: (1) environment, (2) social involvement, (3) tax benefits, (4) higher expected returns, (5) better risk-return trade-off, (6) risk diversification, (7) long investment horizon of SRI, (8) other, (9) I would not (again) invest in SRI, (10) I do not know and (11) I do not want to tell. We classify (3)-(6) as financial reasons. We use the administrative data to distinguish between socially responsible investors that only hold SRI funds without tax benefits, those that hold SRI funds with and without tax benefits and investors that only hold SRI funds with tax benefits.

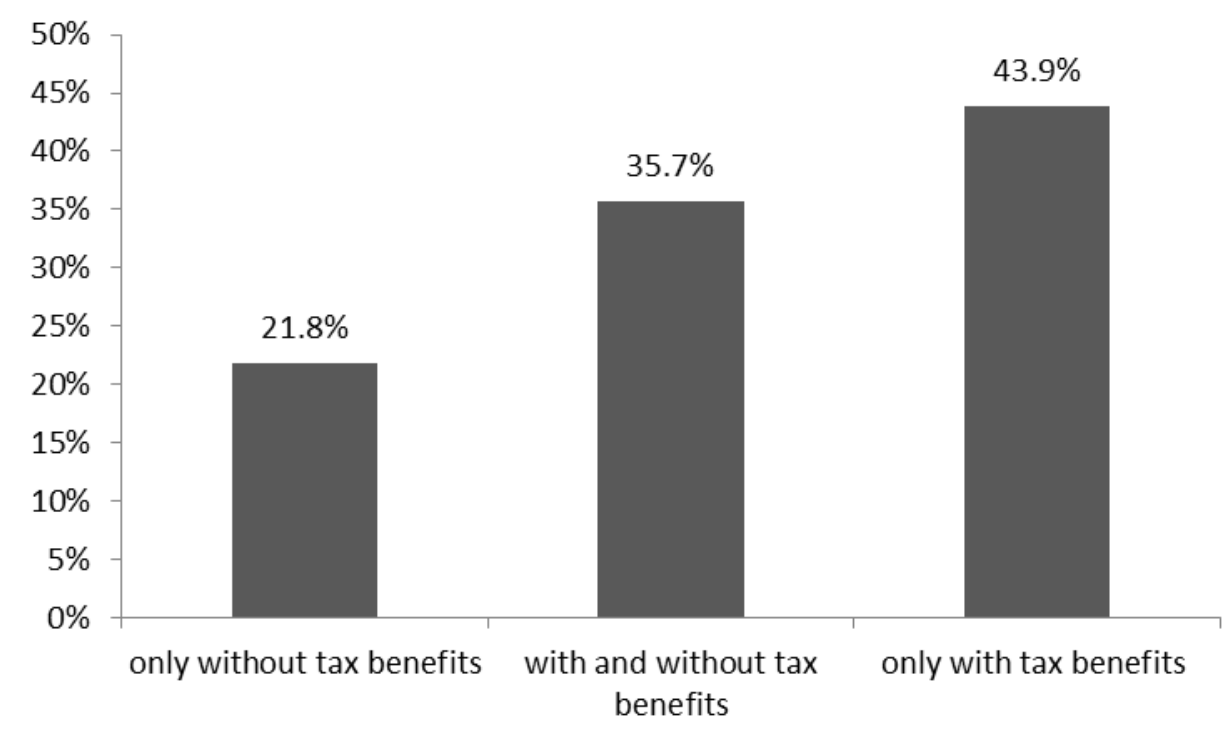




\section{Appendix}

\section{Table A1 - Respondents and overall sample characteristics}

This table compares the mean characteristics of all invited investors to those for the respondents to the survey and experiments. The variables are defined in Table 1. Note that for our research design, we on purpose oversampled socially responsible investors in the survey to increase the power of our analyses in which we compare SR to conventional investors. The response rate for SR investors is $12 \%$ and that for conventional investors is $8 \%$

\begin{tabular}{|l|c|c|}
\hline & $\begin{array}{c}\text { Invited sample } \\
(\mathbf{n = 3 9 , 3 7 9 )}\end{array}$ & $\begin{array}{c}\text { Respondents } \\
(\mathbf{n = 3 , 2 5 4 )}\end{array}$ \\
\hline Female & $24.7 \%$ & $20.6 \%$ \\
\hline Age & 55.5 & 57.9 \\
\hline Total portfolio value (euro) & 61,509 & 74,259 \\
\hline $\begin{array}{l}\text { \% Holds only SRI funds } \\
\text { without tax benefits }\end{array}$ & $7.6 \%$ & $10.2 \%$ \\
\hline $\begin{array}{l}\text { \% Holds only SRI fund } \\
\text { with tax benefits }\end{array}$ & $1.8 \%$ & $2.9 \%$ \\
\hline $\begin{array}{l}\text { \% Holds SRI funds with } \\
\text { and without tax benefits }\end{array}$ & $0.6 \%$ & $0.8 \%$ \\
\hline
\end{tabular}


Table A2 - Design of the risk preferences experiment

\begin{tabular}{|l|lll|l|}
\hline & Safe Payment & & \multicolumn{1}{l|}{ Lottery } \\
\hline 1$)$ & $€ 0$ for sure & or & 50 percent chance of winning $€ 300$ and 50 percent chance of winning $€ 0$ \\
\hline 2$)$ & $€ 10$ for sure & or & 50 percent chance of winning $€ 300$ and 50 percent chance of winning $€ 0$ \\
\hline 3$)$ & $€ 20$ for sure & or & 50 percent chance of winning $€ 300$ and 50 percent chance of winning $€ 0$ \\
\hline 4$)$ & $€ 30$ for sure & or & 50 percent chance of winning $€ 300$ and 50 percent chance of winning $€ 0$ \\
\hline 5$)$ & $€ 40$ for sure & or & 50 percent chance of winning $€ 300$ and 50 percent chance of winning $€ 0$ \\
\hline 6$)$ & $€ 50$ for sure & or & 50 percent chance of winning $€ 300$ and 50 percent chance of winning $€ 0$ \\
\hline 7$)$ & $€ 60$ for sure & or & 50 percent chance of winning $€ 300$ and 50 percent chance of winning $€ 0$ \\
\hline 8$)$ & $€ 70$ for sure & or & 50 percent chance of winning $€ 300$ and 50 percent chance of winning $€ 0$ \\
\hline 9$)$ & $€ 80$ for sure & or & 50 percent chance of winning $€ 300$ and 50 percent chance of winning $€ 0$ \\
\hline 10$)$ & $€ 90$ for sure & or & 50 percent chance of winning $€ 300$ and 50 percent chance of winning $€ 0$ \\
\hline 11$)$ & $€ 100$ for sure & or & 50 percent chance of winning $€ 300$ and 50 percent chance of winning $€ 0$ \\
\hline 12$)$ & $€ 110$ for sure & or & 50 percent chance of winning $€ 300$ and 50 percent chance of winning $€ 0$ \\
\hline 13$)$ & $€ 120$ for sure & or & 50 percent chance of winning $€ 300$ and 50 percent chance of winning $€ 0$ \\
\hline 14$)$ & $€ 130$ for sure & or & 50 percent chance of winning $€ 300$ and 50 percent chance of winning $€ 0$ \\
\hline 15$)$ & $€ 140$ for sure & or & 50 percent chance of winning $€ 300$ and 50 percent chance of winning $€ 0$ \\
\hline 16$)$ & $€ 150$ for sure & or & 50 percent chance of winning $€ 300$ and 50 percent chance of winning $€ 0$ \\
\hline 17$)$ & $€ 160$ for sure & or & 50 percent chance of winning $€ 300$ and 50 percent chance of winning $€ 0$ \\
\hline 18$)$ & $€ 170$ for sure & or & 50 percent chance of winning $€ 300$ and 50 percent chance of winning $€ 0$ \\
\hline 19$)$ & $€ 180$ for sure & or & 50 percent chance of winning $€ 300$ and 50 percent chance of winning $€ 0$ \\
\hline 20$)$ & $€ 190$ for sure & or & 50 percent chance of winning $€ 300$ and 50 percent chance of winning $€ 0$ \\
\hline
\end{tabular}




\section{Table A3 - Likelihood to own a SRI fund - using expected return and perceived risk scores}

This table presents marginal effects of probit regressions in which the dependent variable takes on the value of 1 if an investor holds a SRI mutual fund in the month that he participated in the experiment and survey. In the first specification 'Intrinsic social preferences' is the average return ratio across all possible first mover transfers from 5 euro through 50 euro. In the second specification 'Intrinsic social preferences' is the amount returned by the second mover in the strategy method trust game in units of 10 euro for a maximum transfer of the first mover of 50 euro. All other variables are defined in Table 1. For the variable 'Expected Return SRI' we assign a value of 1 to an investor who expects much lower returns and a value of 5 to an investor who expects much higher returns. The variable 'Perceived Risk SRI' is a 7-point Likert scale where 1 means totally disagree to the statement "socially responsible equity funds are more risky than conventional equity funds' and 7 means completely agree. Standard errors are in parentheses. * is $10 \% * *$ is $5 \%$ and $* * *$ is $1 \%$ significance. 


\begin{tabular}{|c|c|c|}
\hline & $\begin{array}{l}\text { Avg. Return Ratio } \\
\text { (1) }\end{array}$ & $\begin{array}{l}\text { Max. Transfer of } 50 \text { Euro } \\
\text { (2) }\end{array}$ \\
\hline \multicolumn{3}{|l|}{ PREFERENCES } \\
\hline $\begin{array}{l}\text { Intrinsic social } \\
\text { preferences }\end{array}$ & $\begin{array}{l}0.0413 * * \\
(0.0205)\end{array}$ & $\begin{array}{l}0.0081 * * \\
(0.0040)\end{array}$ \\
\hline \multicolumn{3}{|l|}{ BELIEFS } \\
\hline $\begin{array}{l}\text { Expected returns on SRI } \\
(1-5)\end{array}$ & $\begin{array}{c}0.0216 \\
(0.0163)\end{array}$ & $\begin{array}{c}0.0213 \\
(0.0163)\end{array}$ \\
\hline $\begin{array}{l}\text { Perceived risk on SRI (1- } \\
\text { 7) }\end{array}$ & $\begin{array}{c}0.0134 \\
(0.0107)\end{array}$ & $\begin{array}{c}0.0132 \\
(0.0107)\end{array}$ \\
\hline \multicolumn{3}{|l|}{ CONTROLS } \\
\hline Log total portfolio value & $\begin{array}{c}0.0432 * * * \\
(0.0098)\end{array}$ & $\begin{array}{c}0.0428 * * * \\
(0.0098)\end{array}$ \\
\hline Investment knowledge & $\begin{array}{l}0.0195^{*} \\
(0.0106)\end{array}$ & $\begin{array}{l}0.0193^{*} \\
(0.0106)\end{array}$ \\
\hline University degree & $\begin{array}{c}0.0390 \\
(0.0281)\end{array}$ & $\begin{array}{c}0.0383 \\
(0.0281)\end{array}$ \\
\hline Risk preferences & $\begin{array}{l}-0.0003 \\
(0.0003)\end{array}$ & $\begin{array}{l}-0.0003 \\
(0.0003)\end{array}$ \\
\hline Female & $\begin{array}{l}-0.0437 \\
(0.0337)\end{array}$ & $\begin{array}{l}-0.0436 \\
(0.0337)\end{array}$ \\
\hline Age & $\begin{array}{l}-0.0020 \\
(0.0013)\end{array}$ & $\begin{array}{l}-0.0020 \\
(0.0013)\end{array}$ \\
\hline Low income & $\begin{array}{l}0.0276 \\
(0.0360)\end{array}$ & $\begin{array}{c}0.0275 \\
(0.0360)\end{array}$ \\
\hline High income & $\begin{array}{l}-0.0420 \\
(0.0346)\end{array}$ & $\begin{array}{l}-0.0421 \\
(0.0346)\end{array}$ \\
\hline Untold income & $\begin{array}{c}0.0157 \\
(0.0415)\end{array}$ & $\begin{array}{c}0.0154 \\
(0.0415)\end{array}$ \\
\hline Base probability & 0.1570 & 0.1570 \\
\hline $\mathrm{N}$ & & \\
\hline Pseudo R2 & 0.0536 & 0.0538 \\
\hline
\end{tabular}


Table A4 - Probability to invest in a SRI fund with tax benefits and without tax benefits - using back transfer for a max. of 50 euro as social preference measure

This table presents relative-risk ratios of a multinomial logit regression in which the dependent variable can take on four different values. The baseline group (not reported) is conventional investors, the second group is investors who only hold a SRI fund with tax benefits, the third only holds SRI fund without tax benefits and the fourth holds both types of SRI funds. 'Intrinsic social preferences' is the amount returned by the second mover in the strategy method trust game in units of 10 euro for a maximum transfer of the first mover of 50 euro. All other variables are defined in Table 1 . Standard errors are in parentheses. * is $10 \% * *$ is $5 \%$ and $* * *$ is $1 \%$ significance.

\begin{tabular}{|c|c|c|c|}
\hline Only SRI funds & $\begin{array}{c}\text { with tax benefits } \\
\text { (1) }\end{array}$ & $\begin{array}{c}\text { without tax benefits } \\
(2)\end{array}$ & $\begin{array}{l}\text { with and without } \\
\text { tax benefits (3) }\end{array}$ \\
\hline \multicolumn{4}{|l|}{ PREFERENCES } \\
\hline $\begin{array}{l}\text { Intrinsic social } \\
\text { preferences }\end{array}$ & $\begin{array}{c}0.9997 \\
(0.0652) \\
\end{array}$ & $\begin{array}{l}1.0756 * * \\
(0.0348)\end{array}$ & $\begin{array}{c}1.1487 \\
(0.1114) \\
\end{array}$ \\
\hline \multicolumn{4}{|l|}{ BELIEFS } \\
\hline $\begin{array}{l}\text { Lower expected } \\
\text { returns on SRI }\end{array}$ & $\begin{array}{c}1.4312 \\
(0.7574)\end{array}$ & $\begin{array}{c}0.7331 \\
(0.1615)\end{array}$ & $\begin{array}{c}0.5434 \\
(0.3503)\end{array}$ \\
\hline $\begin{array}{l}\text { Lower perceived } \\
\text { risk on SRI }\end{array}$ & $\begin{array}{c}1.5554 \\
(0.7550) \\
\end{array}$ & $\begin{array}{c}0.6993 \\
(0.1576) \\
\end{array}$ & $\begin{array}{c}1.2231 \\
(0.7762)\end{array}$ \\
\hline \multicolumn{4}{|l|}{ CONTROLS } \\
\hline $\begin{array}{l}\text { Log total portfolio } \\
\text { value }\end{array}$ & $\begin{array}{l}1.6813 * * \\
(0.3690)\end{array}$ & $\begin{array}{c}1.2907 * * * \\
(0.1071)\end{array}$ & $\begin{array}{c}2.2807 * * * \\
(0.7314)\end{array}$ \\
\hline $\begin{array}{l}\text { Investment } \\
\text { knowledge }\end{array}$ & $\begin{array}{c}1.8304 * * * \\
(0.4228)\end{array}$ & $\begin{array}{c}1.0794 \\
(0.0942)\end{array}$ & $\begin{array}{c}1.1353 \\
(0.2669)\end{array}$ \\
\hline University degree & $\begin{array}{c}0.4128 \\
(0.2283)\end{array}$ & $\begin{array}{c}1.4217 \\
(0.3325) \\
\end{array}$ & $\begin{array}{l}4.7569 * \\
(3.9589) \\
\end{array}$ \\
\hline Risk preferences & $\begin{array}{c}0.9955 \\
(0.0058)\end{array}$ & $\begin{array}{c}0.9985 \\
(0.0028)\end{array}$ & $\begin{array}{c}0.9961 \\
(0.0086)\end{array}$ \\
\hline Female & $\begin{array}{c}0.6836 \\
(0.5368) \\
\end{array}$ & $\begin{array}{l}0.5294 * \\
(0.1902)\end{array}$ & $\begin{array}{c}3.0479 \\
(2.1169)\end{array}$ \\
\hline Age & $\begin{array}{c}1.0289 \\
(0.0247)\end{array}$ & $\begin{array}{l}0.9790 * \\
(0.0107)\end{array}$ & $\begin{array}{c}0.9552 \\
(0.0323)\end{array}$ \\
\hline Low income & $\begin{array}{c}1.0592 \\
(0.6371)\end{array}$ & $\begin{array}{c}1.2123 \\
(0.3497)\end{array}$ & $\begin{array}{c}2.0091 \\
(1.5704)\end{array}$ \\
\hline High income & $\begin{array}{c}0.0000 \\
(0.0004)\end{array}$ & $\begin{array}{c}0.9089 \\
(0.2810)\end{array}$ & $\begin{array}{c}0.2364 \\
(0.2720)\end{array}$ \\
\hline Untold income & $\begin{array}{c}1.1438 \\
(0.7609)\end{array}$ & $\begin{array}{c}1.0601 \\
(0.3518)\end{array}$ & $\begin{array}{c}0.8330 \\
(0.7622)\end{array}$ \\
\hline $\mathrm{N}$ & & 764 & \\
\hline Pseudo R2 & & 0.0916 & \\
\hline
\end{tabular}




\section{Figure A1 - Website of the mutual fund provider}

Investors buy funds via the product selector on the website of the provider. The product selector presents the investment category and information regarding the performance, fees, investment policies etc.

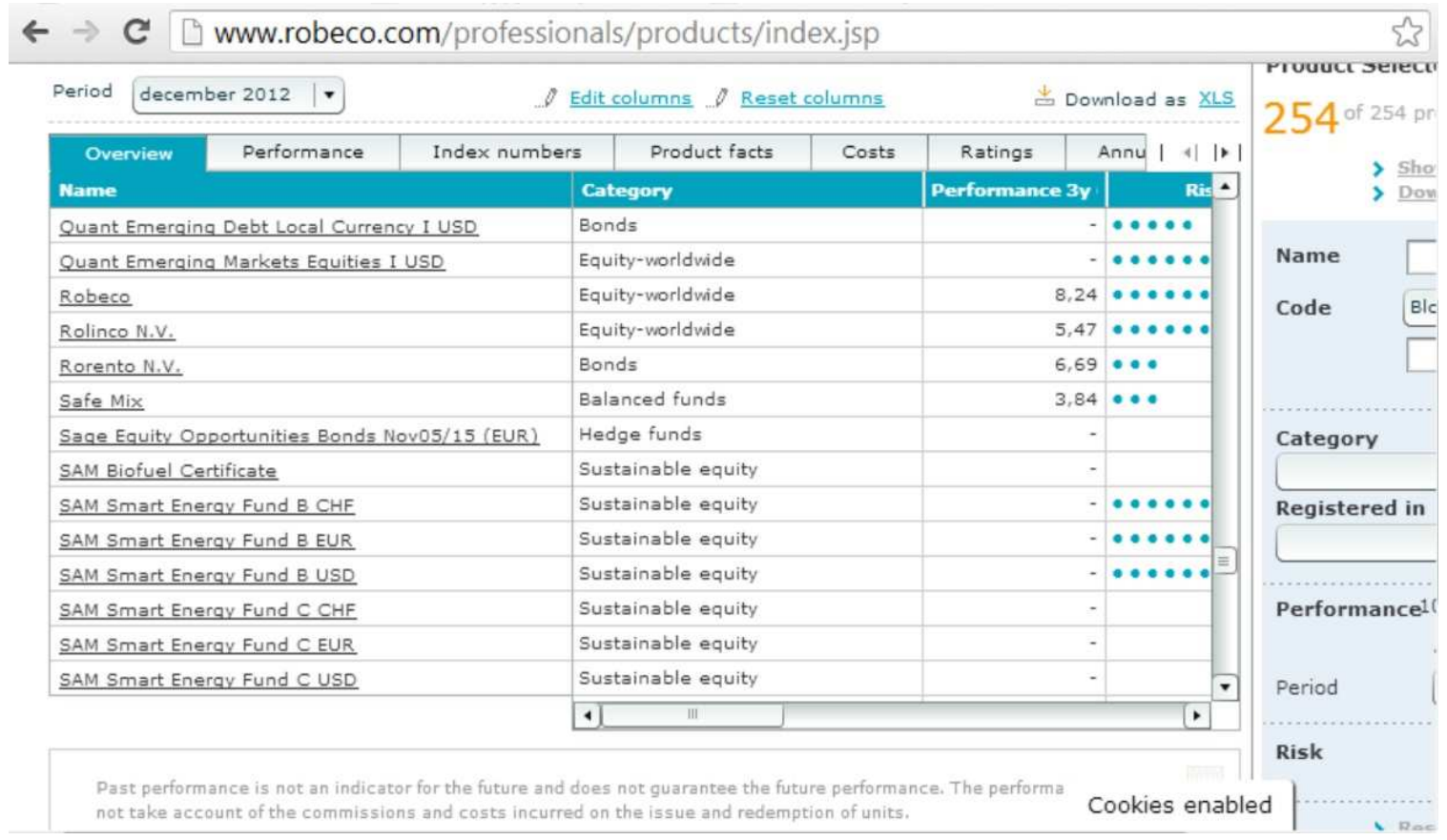




\section{Acknowledgements}

We are grateful to Robeco for providing us with the data for this paper and we in particular thank Peter Jurriaans, Catrien Kleinheerenbrink, Manon Middelink and Jorg Sunderman. This paper benefited from the comments and suggestions of Rob Bauer, John Beshears, Thomas Dohmen, Piet Eichholtz, Uri Gneezy, Arvid Hoffmann, Stephan Meier, Chris Parsons, Thomas Post (Netspar discussant), Tao Shu (EFA discussant), Leonard Wolk and in particular Nicolas Salamanca. We thank seminar participants at EFA 2013 in Cambridge, UC San Diego Rady School of Management, UC San Diego Applied Microeconomics, the $12^{\text {th }}$ Colloquium on Financial Markets in Cologne, Sorbonne University (MISTRA workshop), the EEA 2012 in Malaga, the ESA 2012 in New York, the Netspar annual conference 2012 in Amsterdam, the MBEES 2012 annual conference in Maastricht. We thank Oana Floroiu, Mohammedreza Maghroor, Tobias Ruof, Simone Vermeend and Thorsten Voss for their help as research assistants. We received financial support from MISTRA and the European Centre for Corporate Engagement (ECCE). Part of this paper was written when Paul Smeets was visiting the Rady School of Management (UC San Diego). 